\title{
Mass balance of White Glacier, Axel Heiberg Island, N.W.T., Canada, 1960-91
}

\author{
J. Graham Cogley, W. P. Adams, M. A. Ecclestone \\ Department of Geography, Trent University, Peterborough, Ontario K9J 7B8, Canada \\ F. JUNG-ROTHENHÄUSLER \\ Alfred-Wegener-Institut für Polar- und Meeresforschung, Columbusstraße Postfach 120161, D-2850 Bremerhaven, Germany \\ C. S. L. Ommanney \\ International Glaciological Society, Lensfield Road, Cambridge CB2 IER, England
}

\begin{abstract}
White Glacier is a valley glacier at $79.5^{\circ} \mathrm{N}$ with an area of $38.7 \mathrm{~km}^{2}$. Its mass balance has been measured, over 32 years with a 3 year gap, by standard techniques using the stratigraphic system with a stake density of the order of one stake per $\mathrm{km}^{2}$. Errors in stake mass balance are about $\pm(200-250) \mathrm{mm}$, due largely to the local unrepresentativeness of measurements. Errors in the whole-glacier mass balance $B$ are of the same order as single-stake errors. However, the lag-1 autocorrelation in the time series of $B$ is effectively zero, so it consists of independent random samples, and the error in the long-term "balance normal" $\langle B\rangle$ is noticeably less. $\langle B\rangle$ is $-100 \pm 48 \mathrm{~mm}$. The equilibrium-line altitude (ELA) averages $970 \mathrm{~m}$, with a range of $470-1400 \mathrm{~m}$. Mass balance is well correlated with ELA, but detailed modelling shows that the equilibrium line is undetectable on visible-band satellite images. A reduced network of a few stakes could give acceptable but less accurate estimates of the mass balance, as could estimates based on data from a weather station $120 \mathrm{~km}$ away. There is no evidence of a trend in the mass balance of White Glacier. To detect a climatologically plausible trend will require a ten-fold reduction of measurement error, a conclusion which may well apply to most estimates of mass balance based on similar stake densities.
\end{abstract}

\section{INTRODUCTION}

The mass-balance record of White Glacier, Axel Heiberg Island, Northwest Territories, Canada (Fig. 1), now extends over 32 years, with one 3 year gap. Here we document the record, assess its accuracy, consider alternatives to a stake-based measurement programme and assess the value of White Glacier as an index of climatic change. All of the raw data for this study, and further analytical material, will be found in Cogley and others (1995).

\section{SETTING AND HISTORY OF MEASUREMENTS}

The mean annual precipitation at Eureka, $120 \mathrm{~km}$ northeast of White Glacier, is $58 \mathrm{~mm}$. At Isachsen, $280 \mathrm{~km}$ to the southwest, it is $117 \mathrm{~mm}$. Koerner's (1979) measurements on the eastern and northern sectors of the Müller Ice Cap indicate accumulation of about $160 \mathrm{~mm}$ $\mathrm{a}^{-1}$. Ohmura and Müller (1977) report a 3 year mean for summer precipitation of more than $60 \mathrm{~mm}$, and an increase with elevation at a rate of $72 \mathrm{~mm} \mathrm{~km}^{-1}$, for the White Glacier area. F. Müller (1963d) reports a mean annual accumulation, probably not regionally representative, of about $370 \mathrm{~mm}$ for a 41 year record of annual layers studied in an ice shaft near the highest point on the Müller Ice Cap, $40 \mathrm{~km}$ north of White Glacier. In short, the neighbourhood of White Glacier appears to receive more precipitation than does the nearest weather station at Eureka. The mean annual temperature near sea level at Eureka is $-19.7^{\circ} \mathrm{C}$.

The ice cover of Axel Heiberg Island is described in detail in Ommanney (1969). White Glacier is a compound valley glacier, about $15 \mathrm{~km}$ long and $38.7 \mathrm{~km}^{2}$ in area (Fig. 1). The surface elevation above sea level ranges from $1782 \mathrm{~m}$ down to $75 \mathrm{~m}$, with moraine-covered ice to $53 \mathrm{~m}$. The tongue is about $1 \mathrm{~km}$ wide. Thicknesses, typically $200 \mathrm{~m}$ and up to $400 \mathrm{~m}$, are reported by Becker (1963), Redpath (1965) and Blatter $(1985,1987)$. White Glacier is polythermal, with a cold upper shell and, beneath most of the tongue, a temperate sole (Blatter, 1985, 1987). Surface velocities measured a few kilometres up-glacier from the snout (F. Müller, 1963e) are about $20-30 \mathrm{~m} \mathrm{a}^{-1}$. The snout is retreating at from $3 \mathrm{~m} \mathrm{a}^{-1}(1959-62 ; \mathrm{F}$. Müller and others, 1963) to $5 \mathrm{~m} \mathrm{a}^{-1}(1960-70$; Arnold, 1981). Information in Moisan and Pollard (1992) for 1960-88 is consistent with these estimates. Thompson Glacier (area $\sim 280 \mathrm{~km}^{2}$ ), 


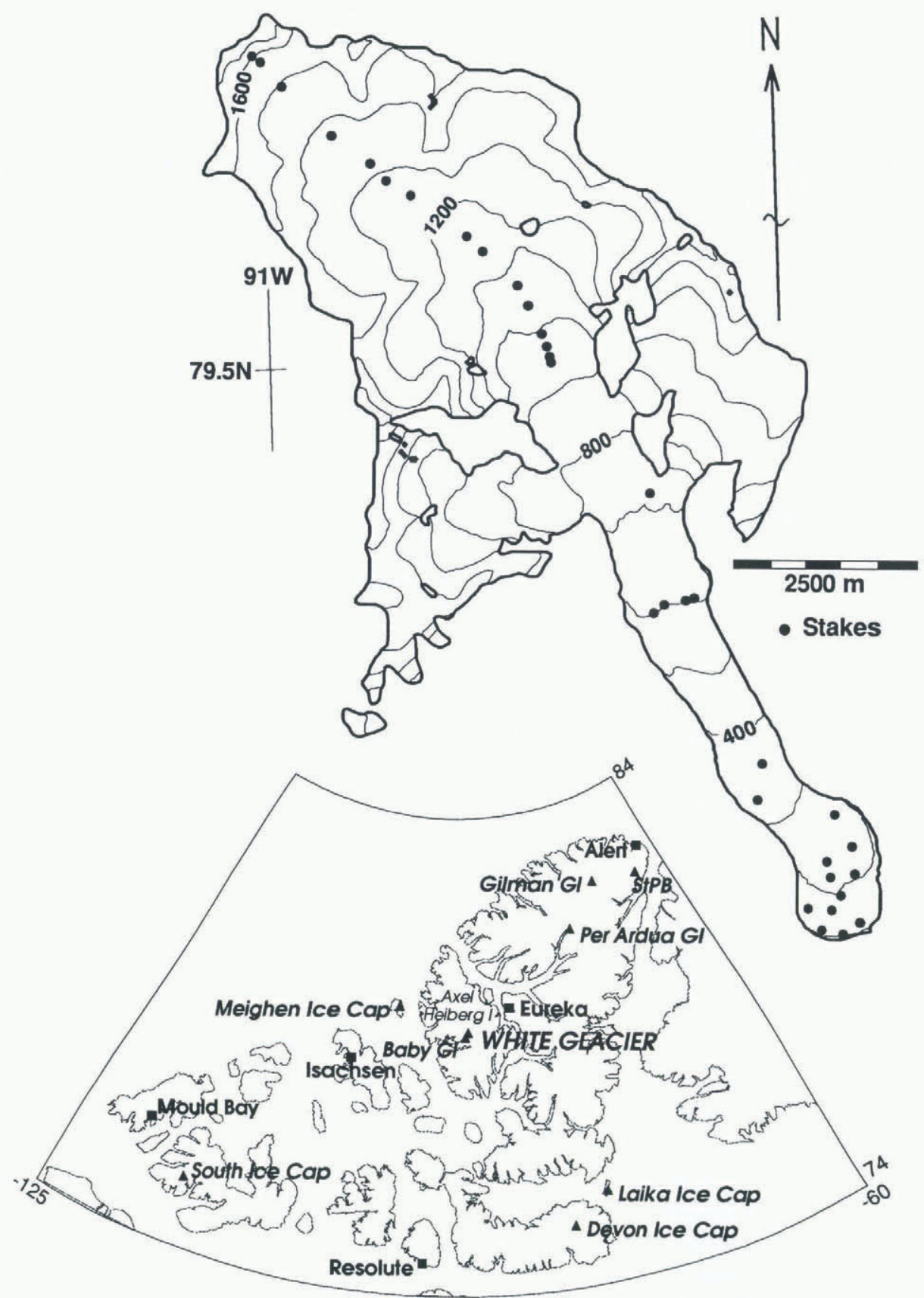

Fig. 1. White Glacier. Longitude, latitude marks at left are each $0.02^{\circ}$ long; contour interval $100 \mathrm{~m}$. Stakes shown are those of 1987. Inset: location of White Glacier and other places mentioned in text; StPB: St Palrick Bay ice caps.

contiguous with the snout of White Glacier, is advancing at $20 \mathrm{ma}^{-1}$.

Mass-balance measurements have been made on White Glacier since 1959. Relevant processes have been studied by, among others, Havens and others (1965: meteorology, climatology), Iken (1974: surface velocities), Blatter (1985, 1987: thermal regime) and Adams and others (1995: equilibrium-zone processes). Ommanney $(1987 \mathrm{a}, \mathrm{b})$ gives a bibliography of glaciological research in the area.

In 1960, an extensive pattern of stakes was established. Müller (1962, 1963c), Adams (1966), Müller and Keeler (1969), Young (1972) and Arnold (1981) have exploited the detailed knowledge of the mass balance for the early years 1960-62.
During 1963-79, annual measurements were made on fewer stakes (varying from 23 to 80 ). These were documented, with annual commentaries, in Weiss (1984). Special projects produced additional measurements in some years (e.g. Arnold, 1981).

There is a gap in the record following the death of F. Müller, the principal investigator. The missing years, 1980, 1981 and 1982, are addressed below.

In 1983, measurements were resumed by groups from Trent University, Canada, and these have continued. The balance for the first year of resumed measurements is probably more uncertain than later estimates. The number of stakes (Fig. 2) has been about 30 per vear or $0.6-0.9$ per $\mathrm{km}^{2}$, to be compared with $2-3$ per $\mathrm{km}^{2}$ in some earlier years. 


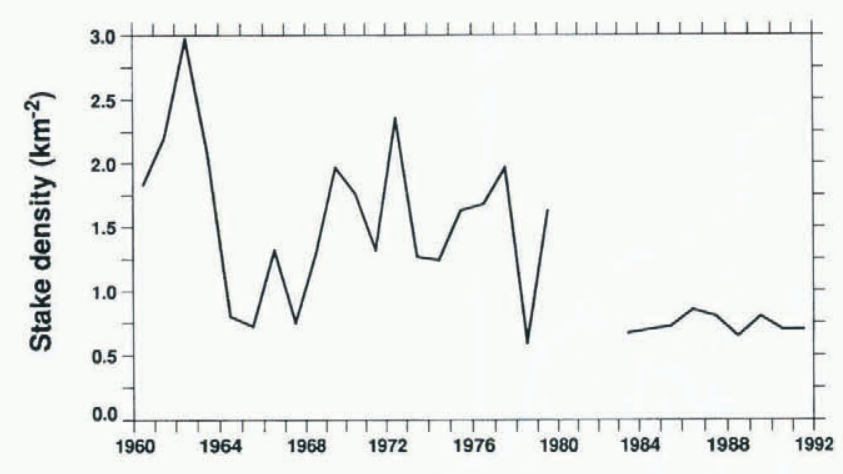

Fig. 2. Density of stakes in each stratigraphic-balance year.

\section{METHODS OF MEASUREMENT}

\section{Definitions}

We use $b$ to denote the net mass balance at any one stake for any one year. The symbol $b(h)$, on the other hand, denotes a 1 year mass-balance estimate made by averaging all the stake measurements in the small range of elevations between $h-\frac{1}{2} \mathrm{~d} h$ and $h+\frac{1}{2} \mathrm{~d} h$. The annual mass balance for the whole glacier is denoted by $B$. The long-term average of $B$ is represented by $\langle B\rangle$ and is called the mass-balance normal. These quantities are quoted as specific balances, in units of mass per unit area per unit time $\left(\mathrm{kg} \mathrm{m}^{-2} \mathrm{a}^{-1}\right.$, or mm water $\left.\mathrm{a}^{-1}\right)$. We refer to stratigraphic years by the calendar year in which they end. Thus, 1960 refers to the mass-balance year 1959-60.

\section{Field methods}

The standard approach to mass-balance work, adopted here, is described in Paterson (1981) and Ostrem and Brugman (1991). We have relied on the stratigraphic system, but with a modification. Resources allow only a single field visit each year, and it is not possible to estimate separate winter and summer balances. The annual visit is therefore made in spring (late May or early June). This allows us to determine with good accuracy the winter accumulation of the current (September-toSeptember) stratigraphic balance year, while in the ablation zone we measure the loss of ice during the previous balance year. The lowering of the ice surface is determined with reference to a mark on a stake (or a thermistor cable) inserted vertically into the glacier. To obtain the stake mass balance $b$ we assume that the lost ice had a density of $900 \mathrm{~kg} \mathrm{~m}^{-3}$.

On polar glaciers, there may be a more-or-less extensive superimposed-ice zone above the equilibrium line (Adams and others, 1995). Especially in hollows, the initial melt refreezes to form superimposed ice at the base of the winter snowpack. At lower elevations the superimposed ice eventually melts, but higher up some of it persists and contributes to net accumulation. Where there is superimposed ice, net accumulation is measured as the rise of the glacier-ice surface with reference to a mark on a stake (times 0.9 to obtain water-equivalent mass, which introduces an error since the density of the superimposed ice is usually less than $900 \mathrm{~kg} \mathrm{~m}^{-3}$ ). Just above the superimposed-ice zone, in the lowest part of the percolation zone, net accumulation is often a combination of snow (measured in pits) and, beneath the snow, "concealed superimposed ice" (measured as a rise of the ice surface against stakes located close to the pits). An added complication is that spatial variations in total accumulation, total melt and formation of superimposed ice produce outliers of accumulation and inliers of ablation.

Above the superimposed-ice zone, pits are dug to identify mass added between the end of one summer and the end of the next. The density of the accumulated volume is determined by identifying distinct layers in the walls of the pit and measuring the density of each layer. The average density is the layer-depth weighted sum of the measured densities. (Before 1983, a complete column of accumulated snow was weighed.)

\section{Calculations}

The net mass balance $B$ for the whole glacier is, by definition,

$$
B=\frac{\int_{\mathcal{A}} b \mathrm{~d} x \mathrm{~d} y}{\int_{\mathcal{A}} \mathrm{d} x \mathrm{~d} y},
$$

where $\mathcal{A}$ is the area covered by the glacier and $b \equiv b(x, y, \Delta t)$ represents the mass balance at each point $(x, y)$ on the glacier over the time-span $\Delta t$. The area is assumed not to change during $\Delta t$. We assume that elevation $h$ is the dominant influence over $b$, and extrapolate from the stakes only in the vertical direction. Measurements of $b$ are grouped into $100 \mathrm{~m}$ high elevation bands, and a function, $\beta(h)$ say, is fitted to $b(h)$, the set of elevation-band averages of the measured $b$. This reduces bias from the uneven distribution of stakes and is consistent with the weighting of elevation-band estimates by their areas $a(h)$ :

$$
B=\frac{\sum_{\mathcal{H}} a(h) \beta(h) \mathrm{d} h}{\sum_{\mathcal{H}} a(h) \mathrm{d} h,}
$$

where the range of summation $\mathcal{H}$ is from the glacier's minimum elevation to its maximum elevation.

As shown below (see also appendix B of Cogley and others, 1995), the structure of the relationship between $b$ and $h$ is relatively simple. $\beta(h)$ is evaluated at the midpoint of every $25 \mathrm{~m}$ elevation band, a relatively fine resolution which takes advantage of hypsometric estimates of the area $a(h)$ derived from a digital elevation model (DEM) by a simple binning routine. The DEM Cogley, 1992a; National Research Council of Canada, $1962 \mathrm{a}, \mathrm{b}, 1965)$ has a horizontal resolution of $50 \mathrm{~m}$. Equation (2) is applied to obtain $B$.

The polynomial $\beta(h)$ always fits the data very well (Cogley and others, 1995). Because polynomials diverge, it is risky to extrapolate them. Beyond the elevation range of the data, therefore, $\beta(h)$ is set to its value at the highest or lowest $h$ at which there is a measurement. The effect of this assumption can be seen in the vertical line segments with which graphs of $\beta(h)$ (shown below) begin and end.

The ELA $h_{0}$ and accumulation area ratio (AAR) are computed by locating the first zero-crossing of the 
polynomial $\beta(h)$, which is accepted as an estimate of $h_{0}$. AAR is simply the ratio of the area above the zerocrossing to total area. The risk of there being more than one zero-crossing, and more generally of the polynomial predicting negative mass balance at high elevations, has to be checked visually. None of the mass-balance years in the current record exhibits this quirk.

\section{Reassessment}

We have detailed stake diagrams and calculations for all years since 1983. All of these have been checked carefully three times, with special attention paid to outliers. Some but not all of the outliers were found to be in error and were corrected or rejected; not all of the detected errors were outliers. We also corrected a few errors in earlier tabulations and transcriptions, including a number of incompatible estimates of stake elevation, which we altered to make the vertical stake trajectories from year to year plausible.

All stake mass balances $b$ are presented by Cogley and others (1995), as are elevation-band averages and standard deviations. Information before 1983 comes from Weiss (1984), for 1963-79; from diagrams and tables in F. Müller (1963a,b) for 1962; and from diagrams in Adams (1966) for 1960-61, including some averages for stake cross-profiles.

\section{ERRORS}

\section{Measurement errors}

Stake mass balances are built up from simple measurements of lengths and weights, which in themselves are rather accurate. Adams (1966) shows that stake readings are accurate to $\pm 5 \mathrm{~mm}$, in the sense that they are reproducible within this range and are representative for an area of several square metres. Measurements of snow density are less accurate (see below), while some uncertainty must arise from the assumption that the density of glacier ice is $900 \mathrm{~kg} \mathrm{~m}^{-3}$. If this is an overestimate, as is possible in the superimposed-ice zone, the ensuing calculations will be biased. We cannot assess this possibility, and a bias in $b$ of up to a few tens of millimetres is quite possible for some stakes.

Differences between stake readings are less accurate than single readings, especially if the stake tilts or settles between the two measurement epochs, or was not vertical to start with. Special problems arise in the superimposedice zone, where the glacier gains mass in the form of refrozen meltwater. Here differences between stake readings may be misinterpreted because the stake appears to have sunk into the glacier. In the lower percolation zone (Adams and others, 1995), next above, an unknown fraction of the added mass is lost to internal accumulation when it melts and percolates, often via pipes of restricted extent, to depths below the current year's snow. This effect is very difficult to quantify, but it must lead to an underestimate of accumulation. We have tried to estimate the losses by inserting pans into the snowpack, but abandoned the method because it was time-consuming and gave poor and doubtful results. We have also tried to measure year-over-year changes of density in the snow beneath that of the current year, but sampling errors tend to be very large. Trabant and Mayo (1985) deduced internal accumulation by measuring the anomalous heating at depth due to the refreezing meltwater, but appropriate measurements are not available for White Glacier.

In the accumulation zone we obtain two estimates of depth, one from the year-to-year difference in stake readings and the other from identification of the previous year's surface in a nearby snow pit. The two depths may be assumed to sample randomly the local variability, which generates uncertainty. For ten such pairs in 1990 and 1991 the standard error was $68 \mathrm{~mm}$ of snow, or on average about $10 \%$ of the average of the two depths. We cannot repeat this exercise for the densities measured in the pit walls, but it seems reasonable to assume an error of the same order; the spring balances used in the field have been checked against a laboratory balance and found to be accurate to better than $\pm 2 \%$, but the error in the sampled volume remains undetermined. Similar errors probably affect the whole-column weights measured before 1983. A $\pm 10 \%$ error in positive values of $b$ will typically be about $\pm(20-30) \mathrm{mm}$ water equivalent.

Since 1987 the elevations of stakes have been measured by altimeter a portable aneroid barometer, calibrated by measuring atmospheric pressure at the known elevation of the base camp). These elevations are considered accurate to within $\pm 5 \mathrm{~m}$. For 1960-62, elevations were estimated from recent maps, and similar estimates seem to have been made up to 1967 , from which date the elevations were based on occasional accurate triangulation. Earlier elevations are regarded as accurate to no better than $\pm 20 \mathrm{~m}$. The impact of this uncertainty is probably negligible, since the stake readings are grouped into $100 \mathrm{~m}$ elevation-band averages before the balance calculations proceed.

\section{Sampling errors}

The greatest uncertainty in $B$ is probably due to undersampling, i.e. to the unrepresentativeness of measurements of $b$ as a sample of the glacier surface. At the local scale (tens to hundreds of metres) glacier surfaces have noticeable microtopography. Prominences must have more negative mass balances than depressions, otherwise the irregular surface, which is steadily regenerated by the internal dynamics of the glacier, would become steadily more irregular. The microclimatic effects of local variations of slope and aspect also amplify the spatial variability of mass balance. On the glacierwide scale, it is impossible to sample areas which are inaccessible or dangerous, and undersampling is likely as well, due for example to uneven coverage of areas exposed to and sheltered from wind or sun.

Lliboutry (1974) modelled ablation-zone stake time series as the sum of a constant stake-dependent term, a time-varying stake-independent term and a Gaussian error term. The error term (i.e., the standard error of any one $b$ ) was about $\pm 200 \mathrm{~mm}$. Young (1981) claims "conservative" standard errors of $20 \mathrm{~mm}$ in the ablation zone and $50 \mathrm{~mm}$ in the accumulation zone of Peyto Glacier, Alberta, Canada, although apparently on a subjective basis. 
Rogerson (1986) estimates an error in $B$ of $\pm 100 \mathrm{~mm}$ for glaciers in Labrador, again subjectively. Pelto (1988) estimated errors of $\pm(150-200) \mathrm{mm}$ for densely sampled small glaciers in the northwestern United States. Braithwaite and Olesen (1989) give errors of $\pm 230 \mathrm{~mm}$, which is the standard deviation of three stakes a few metres apart, and $\pm 280 \mathrm{~mm}$ from Lliboutry's (1974) model, for an ablation zone in southwest Greenland.

Adams (1966) describes White Glacier cross-profiles at various elevations, which sample the (roughly) horizontal variability at hectometre-to-kilometre scales which is not sampled by the stake networks of most later years (Table 1). Standard deviations in the table average $196 \mathrm{~mm}$. Ridges Profile was deliberately established to probe variability in an area of rough microrelief and difficult access, and its standard deviation of $314 \mathrm{~mm}$ may be accepted as an extreme value. The large standard deviation at Moraine Profile in 1961 is due to slush avalanches which introduced superimposed ice into parts of the profile.

Table 1. Error measures from cross-profiles, reanalyzed from Adams (1966). $n$, number of stakes in profile; $\sigma_{\mathrm{b}}$, slandard deviation of cross-profile balances

\begin{tabular}{lcccr}
\hline Profile & Year & $n$ & $\begin{array}{c}\text { Elevation } \\
\text { range } \\
\mathrm{m}\end{array}$ & $\sigma_{\mathrm{b}}$ \\
& & & $\mathrm{mm}$ \\
\hline Moraine & 1960 & 13 & 18 & 149 \\
Moraine & 1961 & 13 & 18 & 292 \\
Anniversary & 1960 & 11 & 52 & 68 \\
Anniversary & 1961 & 11 & 52 & 157 \\
$\begin{array}{l}\text { Ridges } \\
\text { Average }\end{array}$ & 1961 & 20 & 70 & 314 \\
& & & & 196 \\
\hline
\end{tabular}

The stake network on White Glacier is uneven both in space and in time. Stake density is greater on the lower tongue than elsewhere, exceeding two (and in some years ten) stakes per $\mathrm{km}^{2}$, while stake densities are usually 0.5 stakes per $\mathrm{km}^{2}$ or less above about $1000 \mathrm{~m}$. Therefore, uncertainty in the band-averaged balance $b(h)$ is probably greater at higher elevations. In recent years gaps have developed in the coverage, such that there are no stakes at all between 400 and $600 \mathrm{~m}$ or between 800 and $900 \mathrm{~m}$.

The stake network does not cover the entire vertical range of the glacier. Until 1983 the uppermost 10-15\% of the glacier had never been sampled, the highest long-lived stake being at about $1420 \mathrm{~m}$. Since 1983 the highest stake has been at nearly $1600 \mathrm{~m}$, so that extrapolation is required over only about $1 \%$ of the glacier. However, extending the stake network upwards has had minimal effect: for 1983-91, when $B$ is recalculated, the mean difference (balance with new stakes minus balance without) is $2 \mathrm{~mm}$, and the root-mean-square (rms) difference is $8 \mathrm{~mm}$.

Variation in stake density from year to year introduces two kinds of uncertainty. First, when the number of stakes is large the uncertainty ought to decrease; this point is complicated by correlation between stakes, and is discussed below. Secondly, there will be a "missing-stake bias" if a stake cannot be read because of melt-out or burial. Typical accumulation is less than the length of a typical stake $(3.5 \mathrm{~m})$, so burial is not a problem on White Glacier. Stakes in the ablation zone do melt out occasionally; we do not have complete records, but for 1983-91 only three readings out of well over 100 have been lost in this way. (The most common explanation for losing a reading is that the stake is inaccessible for safetyrelated or other reasons; this does not introduce a bias.)

The areas of elevation bands, and of the glacier as a whole, have been assumed constant at values based on surveys dating from 1959-60. The glacier has shrunk since then. The snout is retreating at $3-5 \mathrm{~m} \mathrm{a}^{-1}$ and has a mass balance of about $-2 \mathrm{ma}^{-1}$ (Table 2). Thus, in any cross-section through the snout a (triangular) area of about $\frac{1}{2} \times 4 \times(-2) \mathrm{m}^{2}$ is lost each year but is not accounted for in calculations. Volumetrically, with the snout width taken as $1000 \mathrm{~m}$, this is equivalent to a spurious trend of $-0.1 \mathrm{~mm} \mathrm{a}^{-2}$ in the calculated balance series, or to a balance in 1991 which is $3.2 \mathrm{~mm} \mathrm{a}^{-1}$ too low, and is negligible even if we double or treble it to allow crudely for shrinkage along the sides of the glacier tongue. We also neglect the additional error due to the decrease in total glacier area, which is perhaps $0.3 \mathrm{~km}^{2}$ or $0.8 \%$ over the 1960-91 period.

Finally, the incorrect recording and processing of field measurements is an important source of error. As noted by Braithwaite (1986), mass-balance measurements are usually made by tired observers working in harsh and sometimes dangerous conditions, and so errors are to be expected in field notebooks. There is less excuse for errors made in the office, but they seem to occur nevertheless. These errors are very difficult to find, let alone quantify, but their impact can be reduced greatly by careful double-checking.

Although this discussion is not a rigorous analysis of errors, the conclusion we draw from it is that measurements of $b$ should be considered to have a standard error of about $\pm(200-250) \mathrm{mm}$. In the accumulation zone the errors are greater, by at least a few tens of millimetres, than in the ablation zone, because the measurements are more sparse, and because in places the actual accumulation is either overestimated due to overestimated densities assumed for superimposed ice, or underestimated due to losses by percolation (i.e., internal accumulation).

\section{Errors in whole-glacier mass balance}

Measurements at different stakes are in general highly correlated, so an increase in the number of stakes does not necessarily increase significantly our confidence in the estimate of $B$. If all pairs of stakes give perfectly correlated sequences of results, then our confidence in $B$ is no better than our confidence in each $b$, while at the other extreme perfectly uncorrelated stakes will reduce the uncertainty towards zero as their number grows large. In fact, the White Glacier network exhibits very high correlation between stakes (Fig. 3), such that it is prudent to take the uncertainty in single-stake $b$ as a good estimate 
Table 2. Mass balance $\beta(h)(\mathrm{mm})$ by elevation band and year. Elevations are band midpoints. 1750 and $50 \mathrm{~m}$ bands each occupy less than $0.2 \%$ of area, and are omitted; they contain no stakes, and their estimates are extrapolated by setting them equal to the highest/lowest band with stakes. The rightmost column is affected by round-off error

\begin{tabular}{|c|c|c|c|c|c|c|c|c|c|c|c|c|c|c|c|c|c|}
\hline \multicolumn{18}{|c|}{ Elevation } \\
\hline$(\mathrm{m})$ & 1650 & 1550 & 1450 & 350 & 250 & 1150 & 1050 & 950 & 850 & 750 & 650 & 550 & 450 & 350 & 250 & 150 & \\
\hline$\left(\mathrm{km}^{2}\right)$ & 0.4 & 1.6 & 4.0 & 6.1 & 5.7 & 5.1 & 3.7 & 2.6 & 2.0 & 1.3 & 1.4 & 0.9 & 0.7 & 1.0 & 1.2 & 0.8 & 38.7 \\
\hline & & & & & & & & & & & & & & & & & \\
\hline (0) & 1.1 & 4.1 & 10.4 & 15.8 & 14.8 & 13.1 & 9.5 & 6.7 & 5.1 & 3.4 & 3.7 & 2.3 & 1.9 & 2.7 & 3.1 & 2.0 & 99.7 \\
\hline 960 & 480 & 480 & 470 & 52 & 29 & -287 & -526 & 750 & & & & -1559 & 758 & -1964 & -2179 & -2408 & -404 \\
\hline 961 & 208 & 208 & 245 & 300 & 298 & 246 & 153 & 26 & -127 & -298 & -480 & -665 & -846 & -1013 & -1161 & -1247 & 23 \\
\hline 962 & 407 & 407 & 267 & -68 & -376 & -662 & -929 & -1181 & -1420 & -1651 & -1876 & -2100 & -2325 & -2556 & -2796 & -3047 & -781 \\
\hline 63 & 407 & 407 & 402 & 269 & 107 & -26 & -140 & -249 & -362 & -494 & -654 & -855 & -110 & -1428 & -1823 & -2307 & -154 \\
\hline 964 & 606 & 606 & 604 & 531 & 452 & 402 & 368 & 341 & 310 & 266 & 197 & 95 & -52 & -253 & -520 & -837 & 350 \\
\hline 965 & 200 & 200 & 200 & 216 & 218 & 194 & 143 & 64 & -43 & -179 & -345 & -542 & -771 & -1032 & -1326 & -1593 & -9 \\
\hline 966 & 349 & 349 & 349 & 334 & 282 & 19 & 74 & -71 & -239 & -424 & -621 & -826 & -1035 & -1243 & -1445 & -1615 & -22 \\
\hline 967 & 342 & 342 & 343 & 360 & 357 & 319 & 249 & 152 & 29 & -116 & -282 & -463 & -659 & -866 & -1081 & -12 & 121 \\
\hline 68 & 178 & 178 & 178 & 0 & 33 & -129 & -335 & -574 & -835 & -1105 & -1375 & -1631 & -1864 & -2061 & -2211 & -2298 & -406 \\
\hline 969 & 419 & 419 & 420 & 434 & 412 & 341 & 225 & 73 & -112 & -321 & -551 & & -1042 & -1 & -1 & 49 & 74 \\
\hline 70 & 245 & 245 & 246 & 274 & 271 & 219 & 124 & -5 & -160 & -334 & -520 & -709 & -894 & -1067 & -1220 & -1336 & -4 \\
\hline 971 & 352 & 352 & 352 & 320 & 225 & 77 & -114 & -336 & -576 & -831 & -1082 & -1321 & -1538 & -1720 & -1858 & -1937 & -184 \\
\hline 72 & 287 & 287 & 287 & 270 & 256 & 24 & 237 & 215 & 171 & 98 & -14 & -173 & -389 & -670 & -1025 & -1 & 115 \\
\hline 973 & 348 & 348 & 350 & 391 & 418 & 404 & 352 & 266 & & 5 & -162 & -350 & -555 & -772 & -1000 & -1 & 190 \\
\hline 74 & 225 & 225 & 226 & 223 & 195 & 137 & 54 & -54 & -182 & -328 & -489 & -664 & -848 & -1040 & -1 & & -46 \\
\hline 975 & 588 & 588 & & & & & 383 & 250 & 89 & -96 & -304 & -532 & -776 & -1034 & -1304 & -1538 & 247 \\
\hline 976 & 291 & 291 & 292 & 339 & 364 & 339 & 270 & 164 & 27 & -135 & -315 & -506 & -702 & & 2 & 6 & 112 \\
\hline 77 & 70 & 78 & 81 & 20 & ספ & 121 & -119 & -48 & -833 & -1242 & -1642 & -2000 & -2283 & -2458 & -2493 & -2365 & -372 \\
\hline 978 & 209 & 209 & 210 & 285 & 31 & 229 & 64 & -164 & -435 & -729 & -1025 & -1 & -15 & -1 & -1813 & -1821 & -134 \\
\hline 979 & 196 & 196 & 197 & 226 & 21 & 13 & 9 & -156 & -349 & -556 & -766 & - & -1 & 9 & 7 & 8 & -109 \\
\hline 983 & 160 & 60 & 193 & 315 & . & 279 & 136 & -67 & -314 & -588 & -872 & & & & 7 & & -83 \\
\hline 984 & 338 & 49 & 354 & 326 & 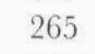 & 17 & 56 & -89 & -258 & -449 & -660 & -889 & -1134 & -1393 & -1664 & -1945 & -55 \\
\hline 985 & 341 & 324 & 286 & 253 & 21 & 177 & 123 & 49 & -51 & -182 & -350 & -563 & -825 & -1144 & -1524 & -1972 & -12 \\
\hline 986 & 125 & 212 & 355 & 386 & & 167 & -56 & -336 & -659 & -1011 & -1380 & -1750 & -2108 & -2440 & -2734 & -2974 & -259 \\
\hline 987 & 47 & 38 & 2 & -62 & -156 & -282 & -441 & -635 & -867 & -1138 & -1449 & -1804 & -2203 & -2649 & -3143 & -3688 & -617 \\
\hline 988 & 427 & 357 & 227 & 163 & 149 & 171 & 210 & 253 & 282 & 283 & 239 & 135 & -47 & -320 & -701 & -1203 & 128 \\
\hline 1989 & 393 & 309 & 150 & 63 & 32 & 42 & 76 & 118 & 152 & 163 & 134 & 49 & -107 & -351 & -698 & -1165 & 28 \\
\hline 990 & 134 & 112 & 44 & -41 & 143 & -263 & -398 & -549 & -716 & -897 & -1092 & -1300 & -1522 & -1756 & -2001 & -2259 & -448 \\
\hline 991 & 333 & 294 & 206 & 130 & 59 & -13 & -91 & -183 & -293 & -429 & -596 & -800 & -1048 & -1346 & -1700 & -2115 & -179 \\
\hline verage & 300 & 296 & 280 & 266 & 203 & 119 & 5 & -134 & -296 & -479 & -679 & -894 & -1122 & -1358 & -1601 & -1836 & -100 \\
\hline
\end{tabular}

of the uncertainty in whole-glacier $B$. There must be some reduction in uncertainty as the number of stakes increases, but the reduction is unlikely to be large and is not investigated further here; it is the subject of work in progress. Nor do we try to infer errors from the reduction of variance achieved by fitting the curve $\beta(h)$. The variation we are trying to infer is not adequately sampled by the observations, so that the good fit of the curves $\beta(h)$ to the data $b(h)$ is not relevant here.

The time series of annual mass balances of White Glacier has a lag-1 autocorrelation of 0. For estimating the balance normal $\langle B\rangle$ this means that we can assume that each $B$ is an independent, random sample of $\langle B\rangle$. Thus the standard error of this long-term average will be inversely proportional to the square root of $N_{y}$, the number of years of record. With $N_{y}=29$ the error in $\langle B\rangle$ is less, by a factor of five or more, than the error in $B$, i.e. about $\pm(40-50) \mathrm{mm}$ rather than $\pm(200-250) \mathrm{mm}$.

\section{RESULTS}

\section{Revised series}

Figure 4 shows $b$ as a function of elevation for all years, with simple linear interpolation between stakes. These are not graphs of $b(h)$ or $\beta(h)$; the tangle of lines illustrates the observed long-term variability of stake mass balance. The largest measured net accumulations are about 500$600 \mathrm{~mm}$ and the largest net losses are as great as $-5000 \mathrm{~mm}$, although typically ablation does not exceed $-3000 \mathrm{~mm}$. This observed range is considerably smaller than that found on many mid-latitude glaciers, especially in maritime climates.

Figure 5 illustrates the polynomial $\beta(h)$ for a small sample of balance years, and Table 2 tabulates $\beta(h)$ for all years, together with flanking data on $a(h)$ and the time average of $\beta(h)$. Table 3 summarizes $B, h_{0}$ and AAR for each 


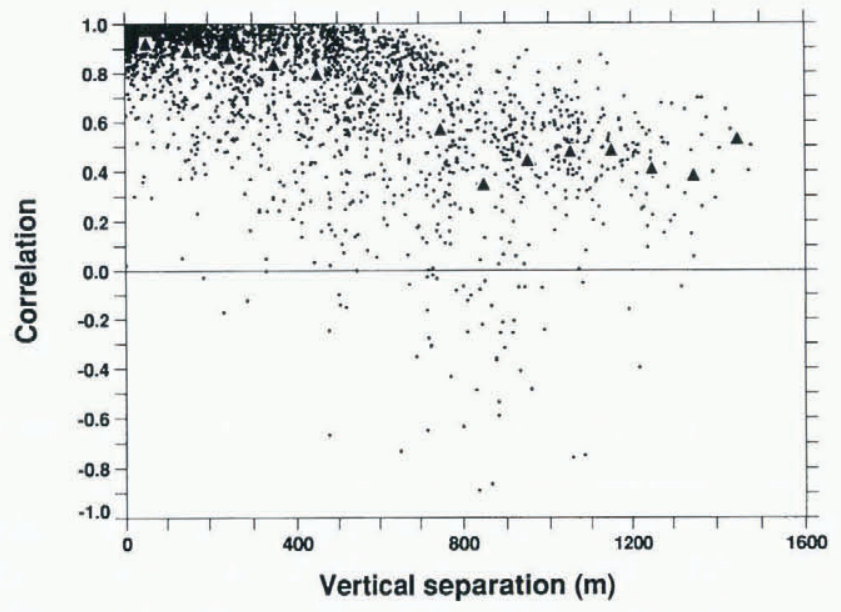

Fig. 3. Balance time-series correlations of 2676 slake pairs vs height difference. Each dot represents two stakes with at least 5 years of common record. Triangles: average correlations within $100 \mathrm{~m}$ wide bins on horizontal axis. Three-quarters of stake pairs differ in height by less than $610 \mathrm{~m}$; four-fifths have correlations exceeding +0.6 .

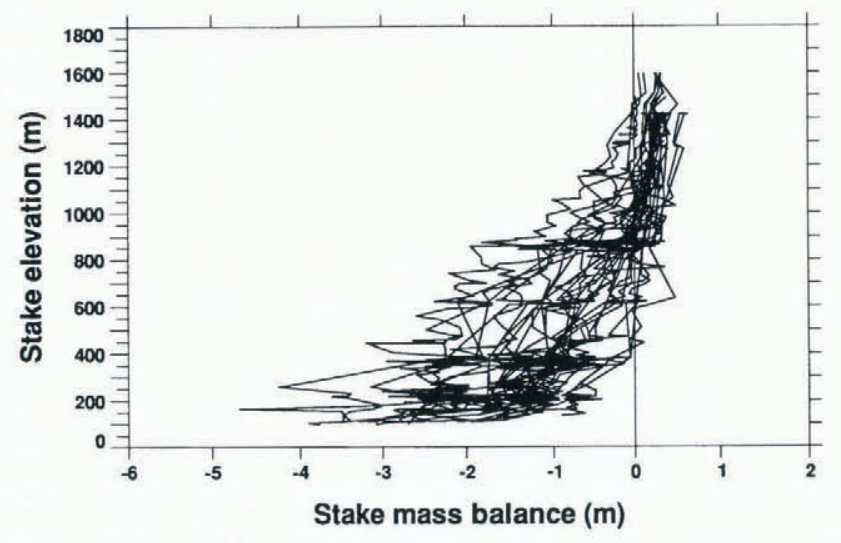

Fig. 4. Stake mass balances for all years, 1960-91, with linear interpolation between stakes. All stakes that survived our reassessment are shown. These graphs show all of the raw measurements on which the mass-balance calculations of this paper are based.

year. The balance normal $\langle B\rangle$, i.e. the average of the 29 values of $B$ in Tables 2 and 3 , is $-100 \mathrm{~mm} \mathrm{a}^{-1}$, while the average $h_{0}$ is $974 \mathrm{~m}$ and the average AAR is 0.65 . The estimate of $h_{0}$ is representative of values estimated by simpler, visual methods for the locality, and the AAR is close to what would be expected from observation of mountain valley glaciers in many parts of the world.

\section{Alternative estimates of mass balance}

The expense and difficulty of fieldwork make more economical methods of mass-balance measurement attractive. This subsection deals with some previous estimates of the mass balance of White Glacier, and with the calibration of some alternative methods. The alternative mass-balance time series discussed here may be found in Table 4 .
Table 3. Mass balance and related properties. $n$, number of stakes; $B$, annual whole-glacier mass balance; $h_{0}$, equilibrium-line altitude; AAR: accumulation area ratio (area of accumulation zone divided by area of glacier)

\begin{tabular}{lrrrr}
\hline Year & $n$ & $B$ & $h_{0}$ & AAR \\
& & $\mathrm{mm}$ & $\mathrm{m}$ & \\
& & & & \\
\hline 1960 & 71 & -404 & 1261 & 0.40 \\
1961 & 85 & 23 & 931 & 0.74 \\
1962 & 115 & -781 & 1371 & 0.20 \\
1963 & 80 & -154 & 1171 & 0.50 \\
1964 & 31 & 350 & 480 & 0.91 \\
1965 & 28 & -9 & 886 & 0.77 \\
1966 & 51 & -22 & 996 & 0.69 \\
1967 & 29 & 121 & 828 & 0.80 \\
1968 & 50 & -406 & 1225 & 0.43 \\
1969 & 76 & 74 & 908 & 0.76 \\
1970 & 68 & -4 & 953 & 0.73 \\
1971 & 51 & -184 & 1107 & 0.59 \\
1972 & 91 & 115 & 659 & 0.86 \\
1973 & 49 & 190 & 746 & 0.82 \\
1974 & 48 & -46 & 997 & 0.69 \\
1975 & 63 & 247 & 800 & 0.81 \\
1976 & 65 & 112 & 832 & 0.80 \\
1977 & 76 & -372 & 1093 & 0.59 \\
1978 & 23 & -134 & 1018 & 0.67 \\
1979 & 63 & -109 & 1043 & 0.65 \\
1983 & 26 & -83 & 980 & 0.71 \\
1984 & 27 & -55 & 1009 & 0.69 \\
1985 & 28 & -12 & 897 & 0.76 \\
1986 & 33 & -259 & 1072 & 0.62 \\
1987 & 31 & -617 & 1444 & 0.09 \\
1988 & 25 & 128 & 470 & 0.91 \\
1989 & 31 & 28 & 511 & 0.90 \\
1990 & 27 & -448 & 1395 & 0.16 \\
1991 & 27 & -179 & 1168 & 0.50 \\
Average & 51 & -100 & 974 & 0.65 \\
& & & & \\
\hline & & & &
\end{tabular}

Previously published estimates

Mass-balance data for White Glacier were first described in B. S. Müller (1961) for 1960 and 1961, and F. Müller and others (1963) for 1960-62, with further reports by Adams (1966), Young (1972), Arnold (1981) and Weiss (1984).

The record is published in Fluctuations of Glaciers (F. Müller, 1977; Haeberli, 1985; Haeberli and Hoelzle, $1993)$, but with an unfortunate recording error: one series reported from Trent University was displaced by 1 year, such that the published balances for 1984-89 are actually those for 1983-88 (i.e., for the balance years 1982-83 to 1987-88). The rms difference between the published series (as corrected: Table 4) and the new series reported here is $39 \mathrm{~mm}$, attributable to the correction of stake data during reassessment and to the substitution of automated for visual curve fitting in the estimation of $\beta(h)$. This is well within the standard error for stake measurements $b$.

Estimates from ELA

Many authors have noted that glacier mass balance is 
Table 4. Estimates of the mass balance $(\mathrm{mm})$ of White Glacier by different methods

\begin{tabular}{|c|c|c|c|c|c|c|}
\hline Year & $\begin{array}{c}\text { This } \\
\text { Work }\end{array}$ & $F l G l^{*}$ & $\begin{array}{l}\text { Visual } \\
\text { method }\end{array}$ & $\begin{array}{l}\text { Glenday } \\
\text { (1989) }\end{array}$ & From $h_{0}$ & $\begin{array}{l}\text { Tongue } \\
\text { stakes }\end{array}$ \\
\hline 1960 & -404 & -410 & -404 & & -347 & \\
\hline 1961 & 23 & 60 & 50 & & -53 & \\
\hline 1962 & -781 & -780 & -745 & & -392 & \\
\hline 1963 & -154 & -140 & -100 & & -269 & \\
\hline 1964 & 350 & 350 & 410 & & 330 & \\
\hline 1965 & -9 & -20 & 20 & & -22 & \\
\hline 1966 & -22 & -30 & 30 & & -118 & \\
\hline 1967 & 121 & 140 & 130 & & 28 & \\
\hline 1968 & -406 & -430 & -360 & & -316 & \\
\hline 1969 & 74 & 50 & 50 & & -41 & \\
\hline 1970 & -4 & -10 & -20 & 129 & -80 & \\
\hline 1971 & -184 & -200 & -190 & -214 & -213 & \\
\hline 1972 & 115 & 100 & 110 & 2 & 175 & \\
\hline 1973 & 190 & 180 & 180 & 152 & 100 & \\
\hline 1974 & -46 & -70 & -60 & -26 & -118 & \\
\hline 1975 & 247 & 240 & 250 & 90 & 53 & \\
\hline 1976 & 112 & 130 & 130 & 116 & 25 & \\
\hline 1977 & -372 & -380 & -380 & -288 & -201 & \\
\hline 1978 & -134 & -140 & -140 & 20 & -137 & \\
\hline 1979 & -109 & -90 & -90 & -122 & -158 & \\
\hline 1980 & & & & -178 & & \\
\hline 1981 & & & & -175 & & \\
\hline 1982 & & & & -92 & & \\
\hline 1983 & -83 & -104 & -120 & 5 & -103 & -123 \\
\hline 1984 & -55 & -64 & -70 & -83 & -128 & -92 \\
\hline 1985 & -12 & -16 & -40 & -100 & -31 & -87 \\
\hline 1986 & -259 & -304 & -330 & & -183 & -372 \\
\hline 1987 & -617 & -790 & -670 & & -506 & -603 \\
\hline 1988 & 128 & 91 & 110 & & 339 & 57 \\
\hline 1989 & 28 & & 10 & & 304 & 102 \\
\hline 1990 & -448 & & -470 & & -463 & -213 \\
\hline 1991 & -179 & & -190 & & -266 & -160 \\
\hline \multicolumn{2}{|c|}{ rms difference ${ }^{\S}$} & 39 & 31 & 90 & 122 & 99 \\
\hline
\end{tabular}

* Estimates published in Fluctuations of Glaciers, Vols. III, IV and VI (F. Müller 1977; Haeberli 1985; Haeberli and Hoelzle 1993). (An error in the published dating of post-1982 results has been corrected: all have been moved one year earlier.)

$\dagger$ Estimates obtained by visual fitting of the function $\beta(h)$ to stake mass-balance data; this method was replaced by automated polynomial fitting during our reassessment of the record.

$\ddagger$ Estimates obtained from a regression model relating results from a network of five stakes on the glacier tongue to results from the whole glacier.

$\S$ Root of mean of squared difference between column and This Work column.

well correlated with elevation of the equilibrium line (e.g. Koerner, 1970; Ostrem, 1975; Braithwaite, 1984; Hagen and Liestol, 1990; Kulkarni, 1992). The relationship is to be expected from the success of Lliboutry's (1974) model, which decomposes stake data sets into a stake-dependent function (i.e. an algebraic representation of the shape $\beta(h))$, a time-dependent function representing the translation of the shape, and an error term.

The result of a simple first-order regression for White Glacier is

$$
B=771-0.894 h_{0}
$$

where $h_{0}$ is in $\mathrm{m}$ a.s.l., and $B$ in $\mathrm{mm}$. The standard error of the estimate of $B$ is $126 \mathrm{~mm}$, and the explained variance $r^{2}$ is $77 \%$. Model performance is illustrated in Figure 6 and Table 4 . The model is simply a rearrangement of existing information, $h_{0}$ having been derived from the same data as were used to estimate $B$. But independent measurements of $h_{0}$ are possible, and the 
Area (per cent)

$\begin{array}{llllll}0 & 1 & 2 & 3 & 4 & 5\end{array}$

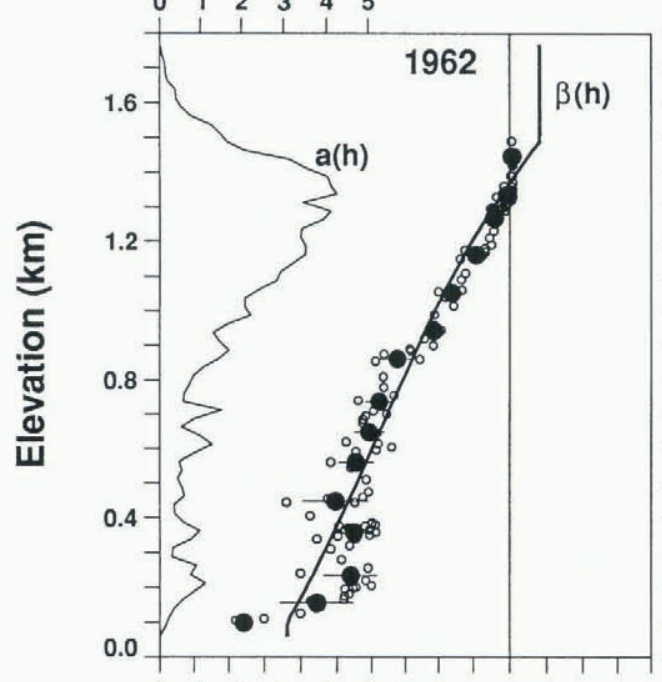

Area (per cent)

$\begin{array}{llllll}0 & 1 & 2 & 3 & 4 & 5\end{array}$

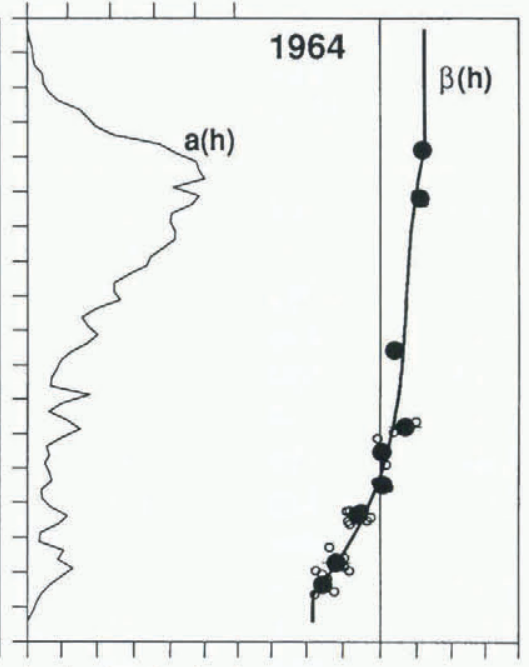

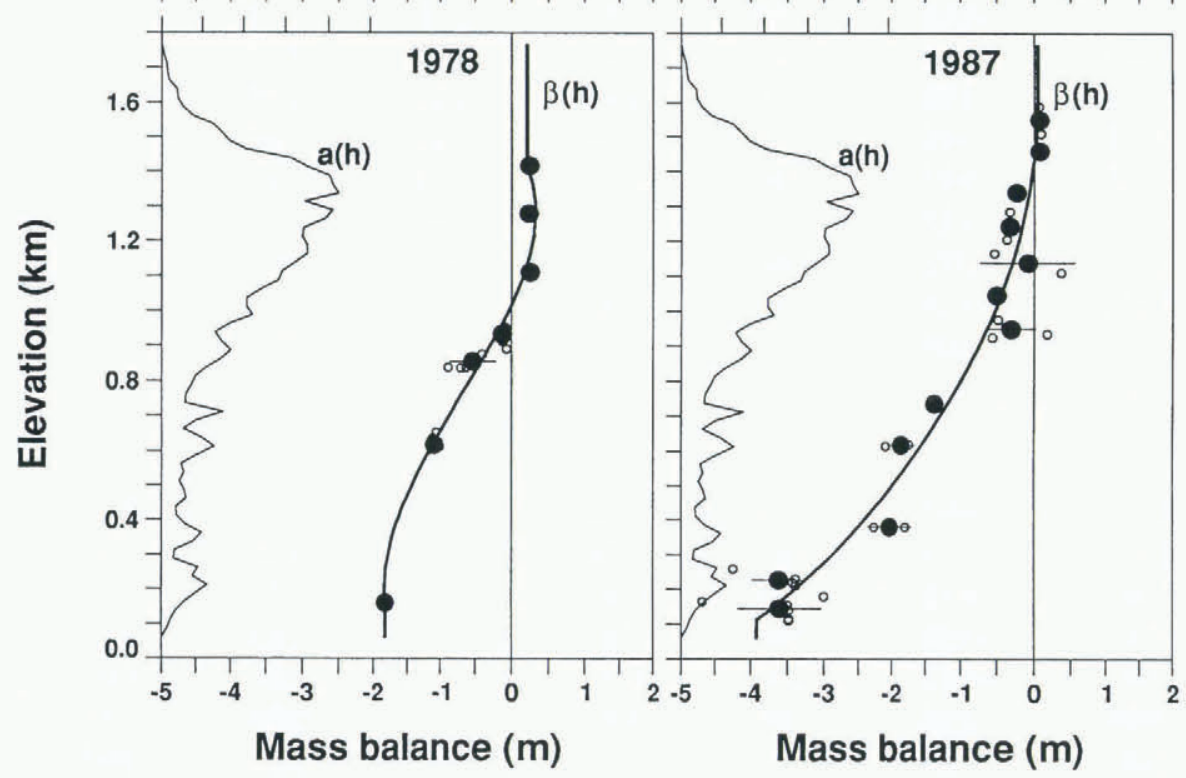

Fig. 5. $\beta(h)$ in four different years: least (1978) and greatest (1962) numbers of stakes, and most positive (1964), most negative (1962) and second most negative (1987) mass balances. Thick lines: third-order polynomial $\beta(h)$. Thin lines: $a(h)$, the hypsometric curve of the glacier. Small open circles: measured stake mass balances. Large solid circles: $b(h)$ for $100 \mathrm{~m}$ elevation bands. Standard deviation of measurements within each band is shown as an error bar; in bands with 0 or 1 measurement there is no bar, but even with several measurements the error bar is sometimes invisible because it is narrower than the symbol for $b(h)$.

relationship suggests that they are likely to be useful.

Whether such a model is useful in practice depends on whether $h_{0}$ can be determined economically, for example from satellite imagery. Independent estimates of $h_{0}$ are likely to have errors uncorrelated with those in $B$. Therefore the error in the regression may be added in quadrature (i.e., we add the variances) to the error of $\pm(200-250) \mathrm{mm}$ in the measured $B$, in order to estimate the total error, about $\pm(235-280) \mathrm{mm}$, in the hypothetical space-based estimate of $B$. The extra cost - an added uncertainty of $(35-50) \mathrm{mm}$ - seems attractive when set against the saving achieved on fieldwork expenses (partly offset by the cost of imagery).

Jung-Rothenhäusler and others (1992) and JungRothenhäusler (1993) discuss measurement of $h_{0}$ from space, and illustrate some of the reasons why early expectations (e.g. Ostrem, 1975) have not been realized.
For example, there is only a handful of suitable end-ofseason images of White Glacier from the entire Landsat series of satellites. Moreover, much of the surface texture which helps the human observer to tell snow apart from glacier ice is fine-scaled, and is lost in satellite pixels having dimensions of $10-100 \mathrm{~m}$. A detailed investigation of one end-of-season image showed that neither the equilibrium line nor the closely related snowline were detectable. After full correction for atmospheric and topographic effects (Cogley, 1992a, b), the surface reflectance was found to be clearly bimodal, the darker mode representing the glacier tongue, and the brighter mode parts of the accumulation zone. However, the transition was gradual, over a vertical span of at least $150 \mathrm{~m}$, and much of the accumulation zone was in the dark, low-reflectance mode. Jung-Rothenhäusler (1993) adduced two factors to explain this incomplete separa- 

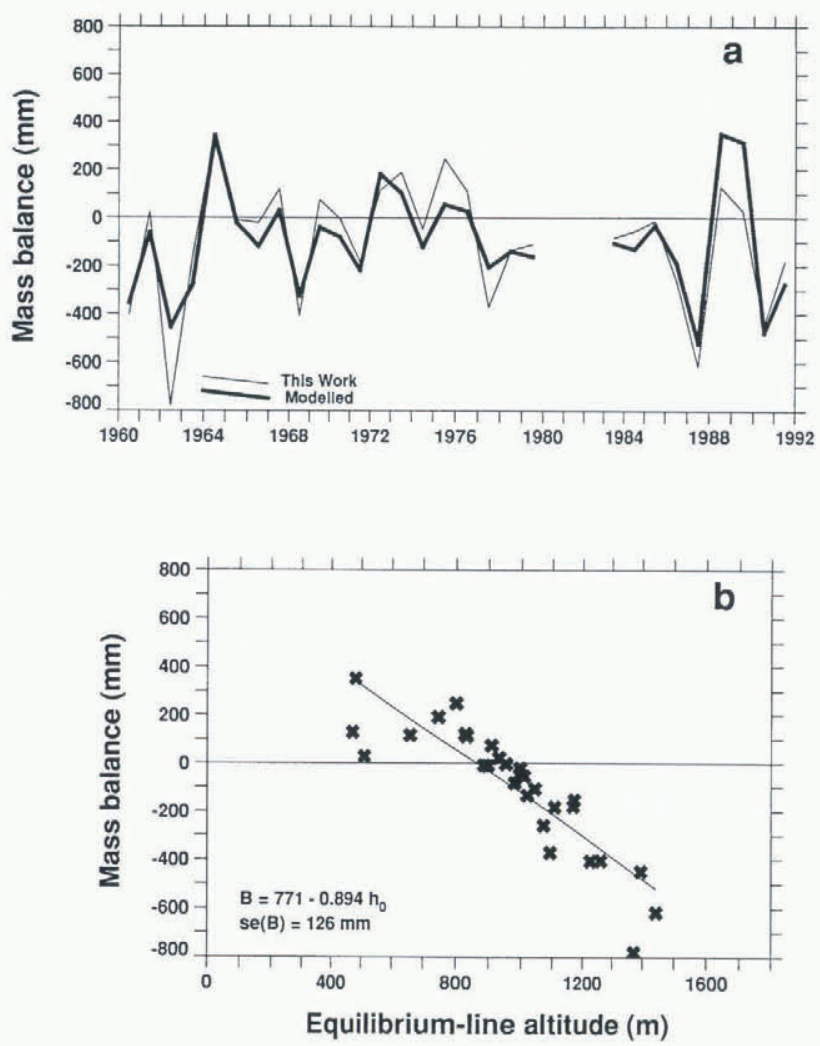

Fig. 6. Whole-glacier balance series as observed " This Work") and as predicted from $h_{0}$ ("Modelled"; Equation (3)). a. Time series; b. scatter graph.

tion: residual errors, and glazing. Glazing produces strong contrasts in reflectance between snow surfaces, and slopes which face the afternoon sun are more likely to be glazed. A rapid transition from dark ice to bright snow, which is a prerequisite for exploiting Equation (3), simply was not present on Jung-Rothenhäusler's Landsat image.

This result seems at odds with the spectacular images often shown as indications of the potential for satellite remote sensing of glacier mass balance. We suspect that such images have either been enhanced, using oversimplified algorithms, or simply do not represent the annual snowline; rather, they are images of transient, bright high-altitude snow cover dating from shortly before the time of the image. The distribution of this transient snow will not in general be related to the position of the annual snowline. Jung-Rothenhäusler's image was unusual in dating from the very end of an ablation season, showing a mature snowpack with reflectance only moderately greater than that of exposed ice.

Thus space-based estimates of $h_{0}$ for White Glacier do not seem to be practicable, at least in the visible spectrum and until understanding of glacier surface reflectance has advanced considerably.

\section{Estimates from reduced networks}

Savings could be realized if we could exploit high interstake correlations (Fig. 3) to infer $B$ from measurements on a few stakes near the snout. This idea is the same as that underlying advocacy of $h_{0}$ as an estimator of $B$.

We examined the series of $b$ at each stake, selecting stakes with records of at least 6 years which correlated with concurrent estimates of $B$ at $r \geq 0.9$, or $r \geq 0.707$ $\left(r^{2}=0.5\right)$ for stakes below $650 \mathrm{~m}$ a.s.l. We then chose subsets of five to ten stakes located close to the snout. Linear regressions of $B$ on $B_{\text {tongue, the (unweighted) }}$ average of $b$ at the subset stakes, were computed over as many years as possible (up to nine). Standard errors were always between \pm 100 and $\pm 120 \mathrm{~mm}$. Figure 7 and Table 4 show the predictive power of a typical subset.

There are statistical objections to this procedure: $B_{\text {tongue }}$ and $B$ are not independent. Nevertheless a reduced stake network could yield useful estimates of mass balance, but with greater uncertainty than the equilibrium-line relationship discussed above. Because $B$ and $B_{\text {tongue }}$ are so highly correlated, the standard error of the regression should be added linearly to the standard error of $B$, giving a total error of about $\pm(300-370) \mathrm{mm}$. The extra uncertainty is a serious penalty, because the only saving is in the time and difficulty of visiting more stakes higher up the glacier. But we conclude that a massbalance estimate need not be forfeited for lack of time, or because of inability to move up-glacier for other reasons.
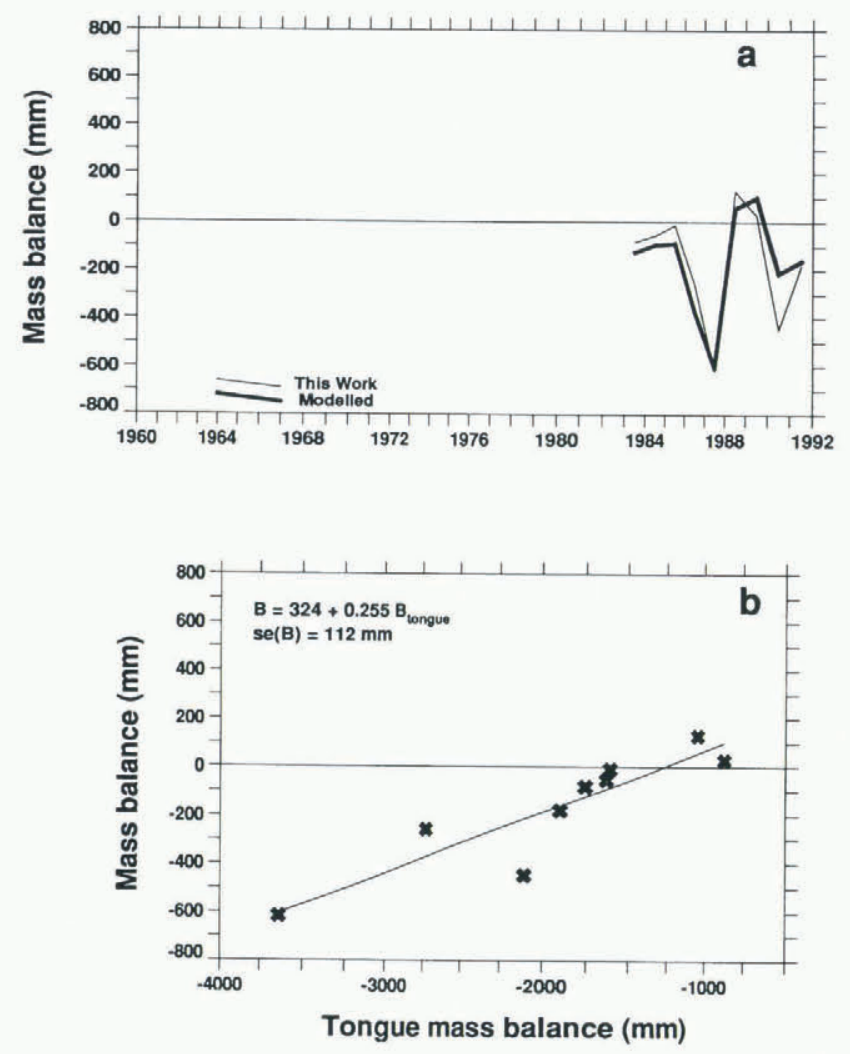

Fig. 7. Whole-glacier balance series as observed ("This Work") and as predicted from five tongue stakes with 9 years of record ("Modelled"). a. Time series; $b$. scaller graph.

\section{Estimates from meteorological data}

Glenday (1989) modelled the mass balance of White Glacier as a function of climatological data. The advantage of such models is that the glacier need not be visited at all; the cost is negligible.

Glenday's best relationship explains $71 \%$ of the 
variance in the mass-balance record (Fig. 8; Table 4):

$$
B=223.9-73.57 T+5.758 P-2.751 K^{*},
$$
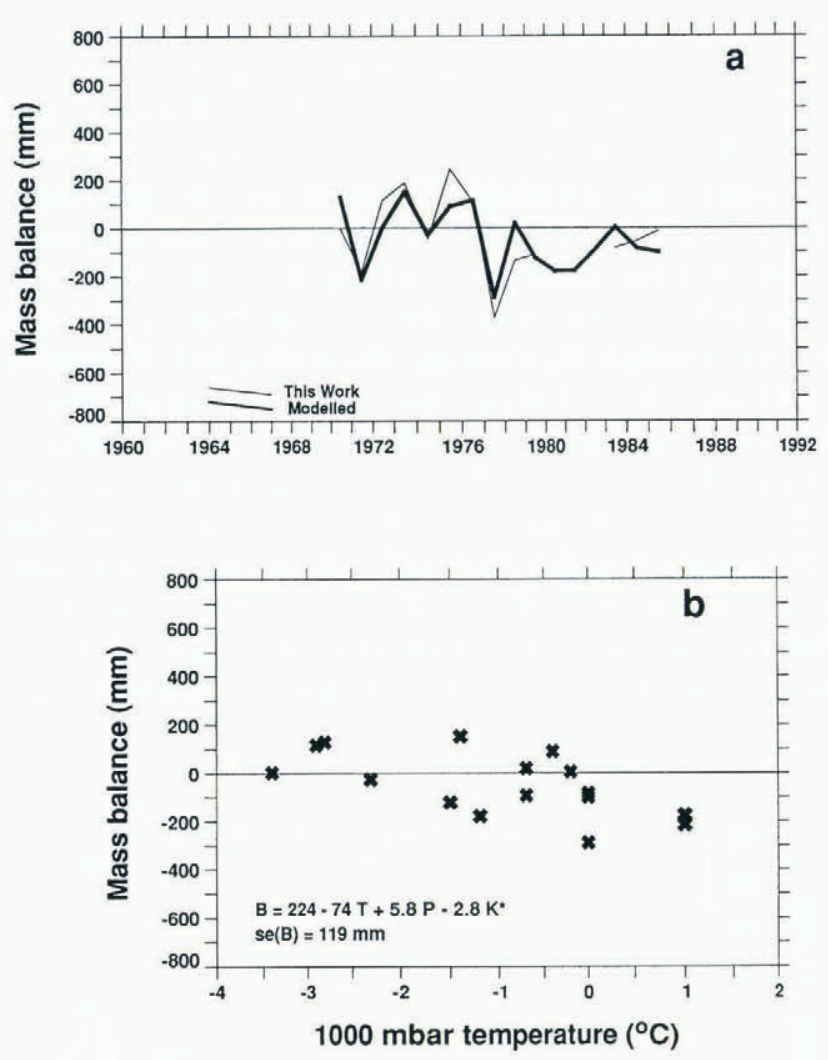

Fig. 8. Whole-glacier balance series as observed ("This Work") and as predicted in terms of weather data from Eureka ("Modelled"; Equation (4)). a. Time series; $b$. scatter graph, projected onto $B-T$ plane. $T$, mean summer (Fune-August) lemperature $\left({ }^{\circ} \mathrm{C}\right.$ ) at 1000 mbar (about $112 \mathrm{~m}$ above surface); $P$, annual precipitation $(\mathrm{mm}) ; K^{*}$, summer average global solar radiation $\left(\mathrm{Wm}^{-2}\right)$. Coefficients yield estimate of $B$ in $\mathrm{mma}^{-1}$.

where temperature $T$, precipitation $P$ and global solar radiation $K^{*}$ are all measured at Eureka (Fig. 1). The standard error of the estimate of $B$ is $\pm 119 \mathrm{~mm}$, to be added in quadrature to the nominal error of $\pm(200-$ $250) \mathrm{mm}$ for a total error of $\pm(230-280) \mathrm{mm}$. Thus, Equation (4) is about as powerful as Equation (3), and has considerable appeal. Of all the alternatives discussed here it is the only one that requires no contact with the glacier, remote or otherwise.

Equation (4) could probably be improved upon. For example Lefauconnier and Hagen (1990) found higher correlations between the mass balance of a glacier in Spitsbergen and climatological quantities from a nearby weather station.

\section{Mass balance for 1980-82}

Stakes were measured on White Glacier in 1981 by J. Weiss. We have readings from 1983 for three of Weiss's 1981 stakes, all of which have remained in use. Their time series of $b$ are well correlated with the time series of $B$ (the correlations being $0.822,0.866$ and 0.882 , with $N_{\mathrm{y}}=9$ in each case), so we can estimate $B$ for the 2 year interval 1980-82 (recalling that measurements in spring refer to the end of the previous balance year). By linear regression, we find the relationship

$$
B=443+0.287 B_{\text {tongue }}
$$

between whole-glacier balance $B$ and the (unweighted) average, $B_{\text {tongue, }}$ of the balances for the three stakes over the nine years $1983-91 ; r$ is 0.95 , and the standard error is $\pm 105 \mathrm{~mm} \mathrm{a}^{-1}$. For the same three stakes, $B_{\text {tongue }}$ for 1980 82 is $-1755 \mathrm{mma}^{-1}$, and hence, from Equation (5), $B=-61 \mathrm{~mm} \mathrm{a}^{-1}$. This estimate has an uncertainty of $\pm(300-350) \mathrm{mm} \mathrm{a}^{-1}$, but it is consistent with meteorological estimates from Equation (4) (Table 4), which average $-148 \mathrm{~mm} \mathrm{a}^{-1}$. Apparently the mass balance during the gap was close to normal.

\section{DISCUSSION}

\section{The balance normal}

The standard error in any single $B$ is $\pm(200-250) \mathrm{mm}$. To estimate the uncertainty in the balance normal $\langle B\rangle$, which is simply the average of all the annual balances, we may take as a starting-point either this estimate or an independent estimate based on the variability in the time series. Mainly because $\pm(200-250) \mathrm{mm}$ is an informal rather than a rigorous estimate of the standard error of $B$, we choose the latter course.

If we assume (e.g. Lyons, 1991) that the $N_{y}$ estimates of $B$ are random, independent samples from a population with finite variance, then the best estimate of the standard error, se $(\langle B\rangle)$, of the normal is equal to the standard deviation, $258 \mathrm{~mm}$, divided by $\sqrt{N_{y}}=\sqrt{29}=5.4 .\langle B\rangle$ for $1960-91$ may thus be quoted as $-100 \pm 48 \mathrm{~mm} \mathrm{a}^{-1}$. se $(\langle B\rangle)$ defines a $\pm 68 \%$ confidence region for $\langle B\rangle$; twice se $(\langle B\rangle)$ defines a $\pm 95 \%$ confidence region. The normal differs from zero by more than two standard errors, so, if our assumptions are justified, we may be $95 \%$ confident that it is negative.

To judge whether the $B$ s are independent of each other, we have computed the lag-1 autocorrelation $r$ (i.e. the correlation of the balance series with a copy of itself offset forwards by one year). If $r$ is not zero, then (Zwiers and von Storch, 1995) the effective sample size might be less than $N_{y}$, and thus the estimated standard error might be too small. However, for White Glacier $r=0.02$, which is indistinguishable from zero.

The coefficient of variation (standard deviation divided by the magnitude of the mean) is 2.6. Thus the mass-balance record is rather noisy, due to natural variability and measurement error.

\section{The balance trend}

Detecting a trend is more difficult than determining the $\operatorname{sign}$ of $B$. Whether an estimate of $\mathrm{d} B / \mathrm{d} t$ is consistent with the true $\mathrm{d} B / \mathrm{d} t$ being zero follows from inspection of the standard error. We risk wrongly accepting the hypothesis that there is a trend, but the risk is readily quantifiable. The hard part is avoiding the error of wrongly concluding 
that $\mathrm{d} B / \mathrm{d} t=0$, i.e. that there is no trend. This risk is enlarged upon below.

The trend and its standard error se $(\mathrm{d} B / \mathrm{d} t)$, in $\mathrm{mm}$ $\mathrm{a}^{-2}$, are both derived from a linear regression of the series $B$ on the time $t$, measured in years since $t_{0}=1960$ :

$$
B(t)=B\left(t_{0}\right)+(\mathrm{d} B / \mathrm{d} t) \times t .
$$

How should we expect glaciers to respond to changes in forcing? In going from one equilibrium to another, a glacier must evolve from $\langle B\rangle=0$ back to $\langle B\rangle=0$ via an excursion. Figure 9 shows the mass balance of a glacier in equilibrium with the climate until time $t_{0}$, when there is a step change in forcing. There is an immediate change in $B$ : the glacier is now either too long and thick or too short and thin, so $B$ becomes negative or positive accordingly. (We assume that $\beta(h)$ varies so that a glacier which is too long will grow shorter, and one which is too short will grow longer. Note that $B$ is a specific quantity, expressed per unit area over the changing total extent of the glacier.) $B$ remains non-zero until the glacier attains the area and thickness appropriate to the new climate, but its magnitude must approach zero more and more closely. In other words, there ought to be a non-zero trend $\mathrm{d} B / \mathrm{d} t$ in the mass balance of a glacier not at equilibrium.

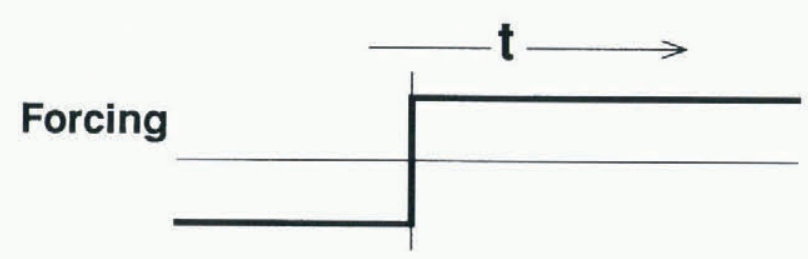

B

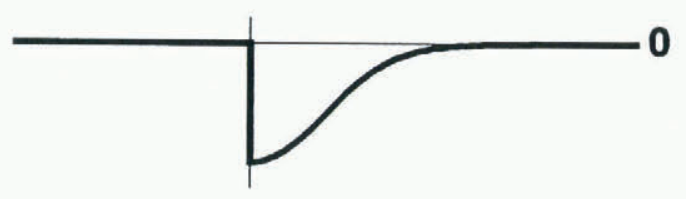

$\mathrm{dB} / \mathrm{dt}$

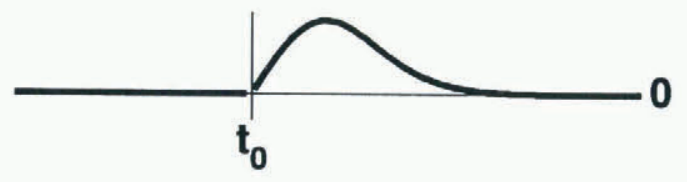

Fig. 9. Schematic response of a glacier to a change in forcing. The climate ("Forcing") changes at time $t_{0}$; the balance $B$, and therefore also the trend $\mathrm{d} B / \mathrm{d} t$, respond accordingly. The shape drawn for $B$ is arbitrary, but in general $\mathrm{d} B / \mathrm{d} t$ is never zero while $B$ is not zero. Only in the limit of a step-function response (i.e. a rectangular shape for $B$ ) will $\mathrm{d} B / \mathrm{d} t$ be zero during adjustment to the allered forcing. Note that we are not regarding the balance as "forcing" for changes in glacier length, as is sometimes done.

For White Glacier, $\mathrm{d} B / \mathrm{d} t$ is estimated as $-2 \pm 5 \mathrm{~mm}$ $\mathrm{a}^{-2}$. Thus the conclusion that $\mathrm{d} B / \mathrm{d} t=0$ seems fairly safe. But it may be a type II error, that of wrongly accepting a false hypothesis. We cannot quantify the risk of such an error, because, of the total stock of information in the data, that on deviations of the observed $B$ from the fitted line has already been "used up" (cf. Lyons, 1991). We need this information on residuals if we are to estimate the probability that $\mathrm{d} B / \mathrm{d} t$ is not 0 (i.e., the risk of a type II error). We must not use it twice. But we were obliged to draw on it when estimating the standard error of the trend, se $(\mathrm{d} B / \mathrm{d} t)$, because we do not have independent estimates of the error in each $B$, only the nominal error of $\pm(200-250) \mathrm{mm}$ derived earlier.

To grasp the practical importance of these uncertainties, consider White Glacier's response time $\tau$, which we may estimate crudely as $\sim 10^{2}$ a because the glacier is $\sim 10^{4} \mathrm{~m}$ long and flows at $\sim 10^{2} \mathrm{~m} \mathrm{a}^{-1}$. Jóhannesson and others (1989), who reanalyze the kinematic-wave model of glacier terminus fluctuations (Hutter, 1983; Lliboutry, 1987 ), suggest calculating $\tau$ as $-H / b_{\text {snout, }}$ where $H$ is a typical thickness, and $b_{\text {snout }}$ the mass balance at the snout. Appropriate values, $H=200 \mathrm{~m}$ and $b_{\text {snout }}=-2 \mathrm{~m} \mathrm{a}^{-1}$, again suggest $\tau \simeq 100$ years. If $\mathrm{d} B / \mathrm{d} t$ is indeed $-2 \mathrm{~mm}$ $\mathrm{a}^{-2}$, and if this trend continued for $\tau$ years, the balance normal would become $-300 \mathrm{~mm} \mathrm{a}^{-1}$ - surely a significant response. But is it physically likely or realistic? From Equation (4), the temperature sensitivity of the balance $\partial B / \partial T$ is $-74 \mathrm{mma}^{-1} \mathrm{~K}^{-1}$, roughly consistent with estimates by Kuhn (1993) based on energy-balance modelling. With predicted warming for the next century of $\partial T / \partial t \sim 0.01-0.03 \mathrm{~K} \mathrm{a}^{-1}$ (Houghton and others, 1990, 1992), a (transient) balance trend $\mathrm{d} B / \mathrm{d} t$ of about -1 or $-2 \mathrm{~mm} \mathrm{a}^{-2}$ should thus be expected in the near future, and perhaps now. This is just what has already been measured, and rejected because of its large uncertainty.

We cannot measure such subtle trends. Natural variability may defeat our best efforts, but it seems that a way must be found to measure mass balances and balance trends with about ten-fold greater accuracy. With the data available now, se $(\mathrm{d} B / \mathrm{d} t)= \pm 5 \mathrm{~mm} \mathrm{a}^{-2}$ is far too large, but with $\operatorname{se}(\mathrm{d} B / \mathrm{d} t)= \pm 0.5 \mathrm{~mm} \mathrm{a}^{2}$ we might already have a firm detection of a climatically plausible trend for White Glacier. To repeat an earlier conclusion: because its mass balance is not zero, there ought to be such a trend.

One line of inquiry which does not depend on improved accuracy is to explore how uncertainties evolve as the available record grows. The result (Fig. 10) shows a slow increase, proportional to $\sqrt{N_{y}}$, in our confidence in estimates of $\langle B\rangle$ and $\mathrm{d} B / \mathrm{d} t$. Given only the first half of the record, we might draw quite misleading conclusions. Two of the most negative balances in the series were measured in its first and third years; presumably this placement is due to chance, but, whatever the reason, it explains why the estimates evolve rapidly in the first half of the record. Only after 25 years can we claim with 95\% confidence that $\langle B\rangle$ is not zero, and a very much longer record will be needed before we can detect with the same confidence that $\mathrm{d} B / \mathrm{d} t$ is not zero.

Are trends detectable in the climatic forcing? Surface temperatures in the Canadian Arctic appear, from the large-scale analyses of Hansen and Lebedeff (1987), Jones (1988) and Folland and others (1990), to have cooled moderately in recent decades, but the trends are not strong. Walsh and Chapman (1990) analyzed station temperature data; none of the Canadian Arctic stations showed significant trends. Kahl and others (1993) show that the tropospheric temperature in the Canadian Arctic during 1958-86 exhibited moderately significant summer 


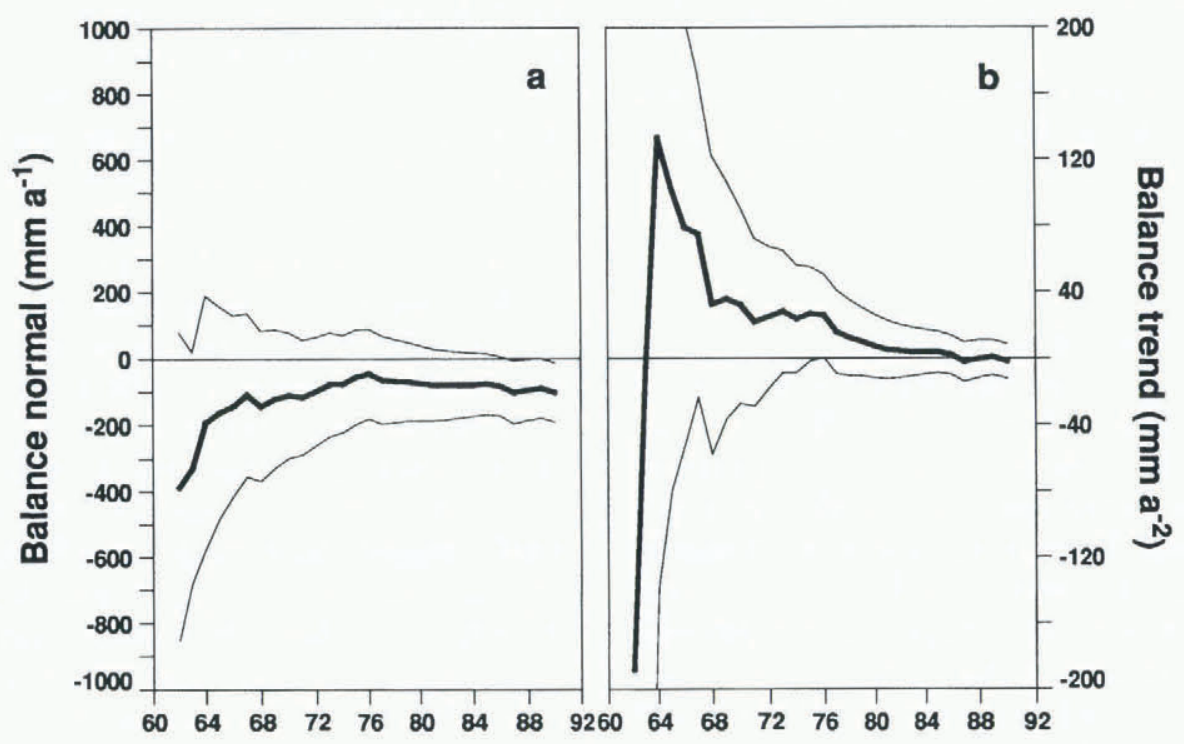

Fig. 10. Evolution of estimates of the balance normal and trend. We step through the record one year at a time, recalculating the normal and trend with the record available to dale. (Except that the information became available in this chronological order, there is no particular reason for stepping forwards through the record, or for starting at the beginning.) Thick lines: estimated normal $(a)$ and trend $(b)$. Thin lines: $95 \%$ confidence regions (i.e. $\pm 2 \times$ standard error of estimate of normal or trend, assuming no serial correlation in the time series). 1980-82 gap filled with estimates from Equation (4).

cooling, at levels up to 300 mbar. It would be interesting to know whether this represents an increase in lapse rate. But as it stands, this study is consistent with the surface studies: no evidence for regional warming in recent decades.

For precipitation, the most recent large-scale compilation (Vinnikov and others, 1990) excludes the Canadian Arctic, so we have used our own data set (Briggs and Cogley, 1990). Precipitation can be highly variable spatially, and in particular altitudinally Ohmura and Müller, 1977). Moreover, it is difficult to measure because gauges, especially snow gauges, tend to undercatch (e.g. Woo and others, 1983). Thus the evidence (Table 5) is of doubtful quality, and is also inconclusive. At three stations there appears to be no trend, while at two there are marginally significant increases. A significant decrease in accumulation was observed by F. Müller (1963d) at a site not far from White Glacier. This record derives from an earlier interval, and the information is described as preliminary, but it adds to a strong impression that no trend in precipitation can be identified with confidence.

Since climatic trends are not evident, it is perhaps unsurprising that trends are not detectable in glacier response to climate. But then (Fig. 9), why is White Glacier's mass balance negative? This paradox illustrates the most important conclusion from the analysis above: with the present technology of mass-balance measurement, the trends which we should expect now and in coming decades will be almost impossible to detect.

\section{The regional balance normal}

We have gathered data for other High Arctic glaciers from literature sources. For each glacier, Table 6 includes basic geographical information as well as the balance normal and, if the record is long enough, the trend. The time-span given may include one or more years without measurements. For three glaciers we present additional multi-year balances based on stake readings more than 2 years apart; in these cases $N_{y}$ is simply the number of years separating the two sets of readings.

Unfortunately the spatial distribution of the glaciers is unfavourable for mapping. To estimate the regional balance normal $\left\langle B_{\mathrm{R}}\right\rangle$, it seems more realistic to settle for a simple regional average. The average of the normals of the five longest records (Table 6), weighted by record length $N_{\mathrm{y}}$, is $\left\langle B_{\mathrm{R}}\right\rangle=-82 \mathrm{mma}^{-1}$. Various weighting schemes such as not weighting at all, including the shorter records, and weighting by extent, all give estimates within $30 \mathrm{~mm} \mathrm{a}^{-1}$ of $-82 \mathrm{~mm} \mathrm{a}^{-1}$. The error in $\left\langle B_{\mathrm{R}}\right\rangle$ is not easy to evaluate, because of spatial autocorrelation and extreme undersampling, but it must be of

Table 5. Annual precipitation at High Arctic weather stations

\begin{tabular}{|c|c|c|c|}
\hline Station & Interval $^{*}$ & $\begin{array}{l}\text { Average } \\
\mathrm{mma}^{-1}\end{array}$ & $\begin{array}{l}\text { Trend } \\
\mathrm{mm} \mathrm{a}^{-2}\end{array}$ \\
\hline Alert & $1960-79$ & $153 \pm 9$ & $-0.5 \pm 1.6$ \\
\hline Eureka & $1960-79$ & $58 \pm 3$ & $1.0 \pm 0.5$ \\
\hline Isachsen & $1960-79$ & $117 \pm 8$ & $2.1 \pm 1.3$ \\
\hline Mould Bay & $1960-79$ & $94 \pm 7$ & $-0.8 \pm 1.2$ \\
\hline Resolute A & $1960-79$ & $129 \pm 7$ & $-0.6 \pm 1.3$ \\
\hline White Crown & & & \\
\hline Mountain ${ }^{\dagger}$ & $1921-61$ & $375 \pm 17$ & $-5.2 \pm 1.2$ \\
\hline
\end{tabular}

* Weather-station data (Briggs and Cogley, 1990) are for calendar years.

$\dagger$ Snow accumulation rate at $1920 \mathrm{~m}$ a.s.l., about $40 \mathrm{~km}$ north of White Glacier (F. Müller 1963d). 
Table 6. Mass-balance series for High Arctic glaciers (Fig. 1). Sources: 1, This work; 2, R. M. Koerner (personal communication, 1994); 3, Blatter and Kappenberger (1988); 4, Bradley and Serreze (1987); 5, Kasser (1973); 6, Alean and Müller (1977); 7, Ommanney (unpublished a); 8, Ommanney (unpublished b); 9, Sagar (1964), Amold (1968)

\begin{tabular}{|c|c|c|c|c|c|c|c|c|c|}
\hline \multirow[t]{2}{*}{ Name } & $\langle B\rangle$ & $\mathrm{d} B / \mathrm{d} t$ & $d$ & Area & $\begin{array}{l}\text { Min-max } \\
\text { elevation }\end{array}$ & Time-span & $N_{\mathrm{y}}$ & Island & Source \\
\hline & $\mathrm{mm} \mathrm{a}^{-1}$ & $\mathrm{~mm} \mathrm{a}^{-2}$ & $\mathrm{~km}$ & $\mathrm{~km}^{2}$ & $\mathrm{~m}$ & & & & \\
\hline White Glacier & $-100 \pm 48$ & $-2 \pm 5$ & 0 & 38.7 & $53-1782$ & $1960-91$ & 29 & Axel Heiberg & 1 \\
\hline Baby Glacier & $-112 \pm 91$ & $3 \pm 11$ & 10 & 0.6 & $715-1175$ & $1960-91$ & 19 & Axel Heiberg & 6,1 \\
\hline Meighen Ice Cap & $-129 \pm 52$ & $7 \pm 5$ & 172 & 85.0 & $70-267$ & $1960-91$ & 30 & Meighen & 2 \\
\hline Devon Ice Cap NW & $-50 \pm 23$ & $1 \pm 3$ & 505 & 1696 & $0-1800$ & $1961-91$ & 30 & Devon & 2 \\
\hline South Ice Cap & $-29 \pm 57$ & $-19 \pm 15$ & 730 & 66.0 & $490-715$ & $1963-74$ & 10 & Melville & 7 \\
\hline South Ice Cap* & -73 & & 730 & 66.0 & $490-715$ & 197480 & 7 & Melville & 7 \\
\hline Gilman Glacier & $-97 \pm 47$ & & 454 & 480 & $410-1850$ & $1957-61$ & 5 & Ellesmere & 9 \\
\hline Gilman Glacier ${ }^{*}$ & -29 & & 454 & 480 & $410-1850$ & $1957-67$ & 11 & Ellesmere & 9 \\
\hline Per Ardua Glacier & -320 & & 339 & 4.7 & $300-1700$ & 1968 & 1 & Ellesmere & 5 \\
\hline Laika Ice Cap & -630 & & 484 & 9.8 & $0-530$ & 1975 & 1 & Coburg. & 3 \\
\hline SPB NE Ice Cap & $20 \pm 54$ & $-8 \pm 14$ & 538 & 7.6 & $850-900$ & $1972-82$ & 6 & Ellesmere & 4,8 \\
\hline SPB NE Ice Cap* & -130 & & 538 & 7.6 & $850-900$ & 1972 & 11 & Ellesmere & 4,8 \\
\hline SPB SW Ice Cap & 165 & & 538 & 3.0 & $740-820$ & 1983 & 1 & Ellesmere & 4 \\
\hline
\end{tabular}

* Multi-year balance.

$d$, Distance from White Glacier.

$N_{y}$, Number of years of record (excluding gaps).

SPB, St Patrick Bay.

the order of the uncertainty in the measured normals $\langle B\rangle$, namely about $\pm 50 \mathrm{~mm} \mathrm{a}^{-1}$.

This estimate of $\left\langle B_{R}\right\rangle$, and Meier's (1984) value of $108600 \mathrm{~km}^{2}$ for the glacierized area of the Canadian High Arctic, give a contribution to sea-level rise of $0.024 \pm$ $0.015 \mathrm{~mm} \mathrm{a}^{-1}$. This estimate is compatible with Meier's $0.019 \mathrm{~mm} \mathrm{a}^{-1}$, but being based on fewer assumptions it is more robust. Thus the Canadian High Arctic, although it contains one-fifth of the world area covered by small glaciers, supplies only one-twentieth of the total smallglacier contribution to rising sea level, estimated by Meier as $0.46 \pm 0.26 \mathrm{~mm} \mathrm{a}^{-1}$.

\section{SUMMARY}

Errors in stake mass balance $b$ are about $\pm(200$ $250) \mathrm{mm}$, due largely to undersampling. Errors in whole-glacier mass balance $B$ are of the same order as single-stake errors. However, the lag-1 autocorrelation of the time series of $B$ is zero, so the error in the long-term average of $B$ is noticeably less. A number of recording and processing errors were detected during reassessment of the record, but we do not think that our work has been less careful than that of other glaciologists. Rather, the errors are a consequence of the complexity and longevity of the enterprise.

The balance normal $\langle B\rangle$ is $-100 \pm 48 \mathrm{~mm} \mathrm{a}^{-1}$, derived from 29 annual measurements of $B$. The reassessed balance series agrees closely with previously published values.

Among less accurate alternatives to the present stakebased programme, a reduced stake network is recom- mended only for salvaging an estimate in difficult field conditions. Hydrometeorological modelling is a practical solution if it is impossible even to visit the glacier. Remote sensing of mass balance is not presently practical, and visible-band imagery may never become a routine tool in the estimation of mass balance.

White Glacier is representative of the Canadian High Arctic, and the dispersion of single glaciers about a regional balance normal of about $-80 \mathrm{~mm} \mathrm{a}^{-1}$ is not very great. The evidence for trends is weak, and in particular White Glacier seems to have a constant mass balance, consistent with a similar absence of evidence for trends in climatic forcing. However, present methods of balance measurement are inadequate for detecting trends of the magnitude to be expected from generalized climatological reasoning.

This is a serious problem for glaciology. Large errors are attached to our estimates, errors which we suspect to be typical of many other mass-balance estimates. A foundation of measurements, however sparse, is essential in monitoring climatic change. But the measurements reported here are rather inaccurate, and all of the cheaper alternatives are even more inaccurate. Research on more accurate ways of estimating mass balance deserves high priority.

\section{ACKNOWLEDGEMENTS}

We gratefully acknowledge the work of all those who have made or assisted with mass-balance measurements on White Glacier. We thank the following organizations that have supported mass-balance work on White Glacier: 
Polar Continental Shelf Project, Energy Mines and Resources Canada; National Hydrology Research Institute, Environment Canada, Saskatoon; Geographisches Institut, ETH, Zürich; Trent University, Canada; the McGill Station, Axel Heiberg Island; the JacobsenMcGill Arctic Research Expeditions; Science Institute, Government of the Northwest Territories. We are also grateful to R. M. Koerner for valuable comments. Finally, we owe a special debt to the late F. Müller, who initiated the programme of glaciological research on Axel Heiberg Island in 1959 and kept it going energetically and insightfully for 20 years until his death in 1980 .

\section{REFERENCES}

Adams, W. P. 1966. Ablation and run-off on the White Glacier, Axel Heiberg Island, Canadian Arctic Archipelago. Montréal, Qué., McGill University. Jacobsen-McGill Arctic Research Expedition 1959-1962. Axel Heiberg Island Research Reports. Glaciology 1. .

Adams, W.P., J.G. Cogley and M. A. Ecclestone. 1995. The equilibrium zone on polar glaciers. Proc. East. Snow Conf., 52nd Annual Meeting, 6-8 June 1995, Toronto, Ontario, 211-218.

Alean, J. and F. Müller. 1977. Zum Massenhaushalt des Baby Glacier, Axel Heiberg Island, Kanadische Hocharktis. Geogr. Helv., 32(4), 203-207.

Arnold, K. C. 1968. Determination of changes of surface height, 1957 1967, of the Gilman Glacier, northern Ellesmere Island, Canada. (M.Sc. thesis, McGill University.)

Arnold, K. C. 1981. Ice ablation measured by stakes and terrestrial photogrammetry - a comparison on the lower part of the White Glacier: Axel Heiberg Island, Canadian Arctic Archipelago. Montréal, Qué., McGill University. (Axel Heiberg Island Research Reports. Glaciology 2.)

Becker, A. 1963. On the determination of glacial depth. (Ph.D. thesis, McGill University.)

Blatter, H. 1985. On the thermal regime of Arctic glaciers: a study of the White Glacier, Axel Heiberg Island, and the Laika Glacier, Coburg Island, Canadian Arctic Archipelago. Zürcher Geogr. Schr., 22.

Blatter, H. 1987. On the thermal regime of an Arctic valley glacier: a study of White Glacier, Axel Heiberg Island, N.W.T., Canada. J. Glaciol., 33 (114), 200-211.

Blatter, H. and G. Kappenberger. 1988. Mass balance and thermal regime of Laika Ice Cap, Coburg Island, N.W.T., Canada. J. Glaciol., 34(116), 102-110.

Bradley, R. S. and M. C. Serreze. 1987. Mass balance of two High Arctic plateau ice caps. 7. Glaciol., 33(113), 123-128.

Braithwaite, R. J. 1984. Can the mass balance of a glacier be estimated from its equilibrium-line altitude? J. Glaciol., 30(106), 364-368.

Braithwaite, R.J. 1986. Assessment of mass-balance variations within a sparse stake network, Qamanârssûp sermia, West Greenland. fy. Glaciol., 32 110$), 50-53$

Braithwaite, R.J. and O. B. Olesen. 1989. Detection of climate signal by inter-stake correlations of annual ablation data, Qamanârssûp sermia, West Greenland. J. Glaciol., 35 (120), 253-259.

Briggs, P.A. and J.G. Cogley. 1990. Creation of the TRE.NTPCP global precipilation dalaset. Peterborough, Ont., Trent University. Department of Geography. (Trent Climate Note 90-3.)

Cogley, J. G. 1992a. Registration of a LANDSAT-1 image to a digital elevation model of the White Glacier using control points. Peterborough, Ont., Trent University. Department of Geography. (Trent Technical Note 92-2.

Cogley, J. G. 1992b. Software for image processing and analysis. Peterborough, Ont., Trent University. Department of Geography. (Trent Technical Note 92-1.

Cogley, J. G., W. P. Adams, M. A. Ecclestone, F. Jung-Rothenhäusler and C.S. L. Ommanney. 1995. Mass balance of Axel Heiberg Island glaciers, 1960-1991: a reassessment and discussion. Saskatoon, Sask. Environment Canada. National Hydrology Research Institute. (NHRI Science Report 6.

Folland, C. K., T. R. Karl and K. Ya. Vinnikov. 1990. Observed climate variations and change. In Houghton, J. T., G.J. Jenkins and J.J. Ephraums, eds. Climate change: the IPCC scientific assessment. Cambridge, etc., Cambridge University Press, 195-238.

Glenday, P.J. 1989. Mass balance parameterization, White Glacier,
Axel Heiberg Island, N.W.T., 1970-80. (B.A. thesis, Trent University.)

Haeberli, W., ed. 1985. Fluctuations of glaciers 1975-1980 (Vol. IV). Paris, International Commission on Snow and Ice of the International Association of Hydrological Sciences/Unesco.

Hacberli, W. and M. Hoelzle, eds. 1993. Fluctuations of glaciers 1985-1990 (Vol. VI). Wallingford, Oxon., IAHS Press; Nairobi, UNEP; Paris, Unesco.

Hagen, J. O. and O. Liestøl. 1990. Long-term glacier mass-balance investigations in Svalbard, 1950-88. Ann. Glaciol., 14, 102-106.

Hansen, J. and S. Lebedeff. 1987. Global trends of measured surface air temperature. 7. Geophys. Res., 92(D11), 13,345-13,372.

Havens, J. M., F. Müller and G.C. Wilmot. 1965. Comparative meteorological survey and a short-term heat balance study of the White Glacier, Canadian Arctic Archipelago-summer 1962. Montréal, Qué, McGill University. (Axel Heiberg Island Research Reports. Meteorology 4.)

Houghton, J. T., G.J. Jenkins and J.J. Ephraums, eds. 1990. Climate change: the IPCC scientific assessment. Cambridge, etc., Cambridge University Press.

Houghton, J. T., B. A. Callander and S. K. Varney, eds. 1992. Climate change 1992: the supplementary report to the IPCC scientific assessment. Cambridge, etc., Cambridge University Press.

Hutter, K. 1983. Theoretical glaciology; material science of ice and the mechanics of glaciers and ice sheets. Dordrecht, etc., D. Reidel Publishing Co. Tokyo, Terra Scientific Publishing Co.

Iken, A. 1974. Velocity fluctuations of an Arctic valley glacier, a study of the White Glacier, Axel Heiberg Island, Canadian Arctic Archipelago. Montréal, Qué, McGill University. (Axel Heiberg Island Research Reports. Glaciology 5. .

Jóhannesson, T., C. Raymond and E. Waddington. 1989. Time-scale for adjustment of glaciers to changes in mass balance. 7 . Glaciol., 35 (12 I), 355-369.

Jones, P. D. 1988. Hemispheric surface air temperature variations: recent trends and an update to 1987. J. Climate, 1, 654660.

Jung-Rothenhäusler, F. 1993. Prospects for remote sensing of the annual mass balance: White Glacier, Axel Heiberg Island, N.W.T., Canada'. (M.Sc. thesis, Trent University.)

Jung-Rothenhäusler, F., J. G. Cogley and W. P. Adams. 1992. Preparations for a glacier study using Landsat imagery and a digital elevation model. Musk-ox, 39, 31-38.

Kahl, J. D. W., M. C. Serreze, R. S. Stone, S. Shiotani, M. Kisley and R. C. Schnell. 1993. Tropospheric temperature trends in the Arctic: 1958-1986. J. Geophys. Res., 98 (D7), 12,825-12,838.

Kasser, P., ed. 1973. Fluctuations of glaciers 1965-1970 (Vol. II). Paris, International Commission on Snow and Ice of the International Association of Hydrological Sciences/UNESCO.

Koerner, R. M. 1970. The mass balance of the Devon Island ice cap, Northwest Territories, Canada, 1961-66. J. Glaciol., 9 (57), 325-336.

Koerner, R. M. 1979. Accumulation, ablation, and oxygen isotope variations on the Queen Elizabeth Islands ice caps, Canada. $f$. Glaciol., 22 (86), 25 -41.

Kuhn, M. 1993. Possible future contributions to sea level change from small glaciers. In Warrick, R. A., E. M. Barrow and T. M. L. Wigley, eds. Climate and sea level change: observations, projections and implications. Cambridge, Cambridge University Press, 134-143.

Kulkarni, A. V. 1992. Mass balance of Himalayan glaciers using AAR and ELA methods. 7. Glaciol., 38 (128), 101-104.

Lefauconnier, B. and J. O. Hagen. 1990. Glaciers and climate in Svalbard: statistical analysis and reconstruction of the Broggerbreen mass balance for the last 77 years. Ann. Glaciol., 14, 148-152.

Lliboutry, L. 1974. Multivariate statistical analysis of glacier annual balances. J. Glaciol., 13(69), 371-392.

Lliboutry, L. A. 1987. Very slow flows of solids: basics of modeling in geodynamics and glaciology. Dordrecht, etc., Martinus Nijhoff Publishers.

Lyons, L. 1991. A practical guide to data analysis for physical science students. Cambridge, etc., Cambridge University Press.

Meier, M. F. 1984. Contribution of small glaciers to global sea level. Science, 226 (4681), 1418-1421.

Moisan, Y. and W.H. Pollard. 1992. Changes at the snout and proglacial zone of the White-Thompson Glacier complex, Axel Heiberg Island, Northwest Territories. Musk-ox, 39, 1-8.

Müller, B.S., ed. 1961. Jacobsen-McGill Arctic Research Expedition to Axel Heiberg Island, Queen Elizabeth Islands: preliminary report of 1959-1960. Montréal, Qué., McGill University.

Müller, F. 1962. Zonation in the accumulation area of the glaciers of Axel Heiberg Island, N.W.T., Canada. J. Glaciol., 4(33), 302-311.

Müller, F. 1963a. Ablation measurements in 1962. In Müller, F. and 18 others, eds. Jacobsen-McGill Arctic Research Expedition 1959-1962; 
preliminary report 1961-1962. Montréal, Qué., McGill University, $37-$ 46. (Axel Heiberg Island Research Reports.)

Müller, F. 1963b. Accumulation studies. In Müller, F. and 18 others, eds. Jacobsen-McGill Arctic Research Expedition 1959-1962; preliminary report 1961-1962. Montréal, Qué., McGill University, 7-25. (Axel Heiberg Island Research Reports.

Müller, F. 1963c. Glacier mass budget and climate (three years of measurements on Axel Heiberg Island). In Müller, F. and 18 others, eds. Jacobsen-McGill Arctic Research Expedition 1959-1962; preliminary report 1961-1962. Montréal, Qué., McGill University, 57-64. (Axel Heiberg Island Research Reports.

Müller, F. 1963d. Investigations in an ice shaft in the accumulation area of the McGill Ice Cap. In Müller, F. and 18 others, eds. Jacobsen-McGill Arctic Research Expedition 1959-1962; preliminary report 1961-1962. Montréal, Qué., McGill University, 27-36. (Axel Heiberg Island Research Reports.

Müller, F. 1963e. Surveying of glacier movement and mass changes. In Müller, F. and 18 others, eds. Jacobsen-McGill Arctic Research Expedition 1959 1962; preliminary report 1961-1962. Montréal, Qué., McGill University, 65-80. (Axel Heiberg Island Research Reports.

Müller, F., ed. 1977. Fluctuations of glaciers 1970-1975 (Vol. III). Paris, International Commission on Snow and Ice of the International Association of Hydrological Sciences/UNESCO

Müller, F. and 18 others. 1963. Jacobsen-McGill Arctic Research Expedition 1959-1962; preliminary report 1961-1962 and map supplement. Montréal, Qué., McGill University. (Axel Heiberg Island Research Reports.)

Müller, F. and C. M. Keeler. 1969. Errors in short-term ablation measurements on melting ice surfaces. f. Glaciol., 8(52), 91-105.

National Research Council of Canada. 1962a. Thompson Glacier region, Axel Heiberg Island, N.W.T., Canada, based on 28 July and 13 August 1959 photography. Montréal, Qué., Photogrammetric Research Section of the National Research Council of Canada in conjunction with the Jacobsen-McGill Arctic Research Expedition to Axel Heiberg Island, N.W.T., McGill University.

National Research Council of Canada. 1962b. White Glacier, Thompson Glacier region, Axel Heiberg Island, Canadian Arctic Archipelago, based on 2 August 1960 photography. Montréal, Qué., Photogrammetric Research Section of the National Research Council of Canada in conjunction with the Axel Heiberg Island Expedition of McGill University.

National Research Council of Canada. 1965. White Glacier, Axel Heiberg Island, Canadian Arctic Archipelago, based on 2 August 1960 photography. Montréal, Qué., Photogrammetric Research Section of the Nationa Research Council of Canada in conjunction with the Axel Heiberg Island Expedition of McGill University.

Ohmura, A. and F. Müller. 1977. Die mesoklimatische Verteilung von Luftemperatur und Niederschlag über der hocharktischen Tundra von Axel Heiberg Island, N.W.T., Kanada. Geogr. Helv., 32 4), $185-194$.

Ommanney, C.S. L. 1969. A sludy in glacier inventory: the ice masses of Axel Heiberg Island, Canadian Arctic Archipelago. Montréal, Qué., McGill University. (Axel Heiberg Island Research Reports, Glaciology 3.)

Ommanney, C.S.L. 1987a. Axel Heiberg Island bibliography. In Adams, P., ed. Field research on Axel Heiberg Island, N.W.T., Canada: bibliographies and data reports with appendices of data from the McGill Subarctic Research Station, Schefferville, P.Q. Montréal, Qué., McGill University. Centre for Northern Studies and Research, 5-55. McGill Subarctic Research Paper 41. Axel Heiberg Island Research Reports. Miscellaneous Papers 2.)
Ommanney, C. S. L. 1987b. Axel Heiberg Island visitations. In Adams, P., ed. Field research on Axel Heiberg Island, N.W.T., Canada: bibliographies and data reports with appendices of data from the McGill Subarctic Research Station, Schefferville, P.Q. Montréal, Qué., McGill University. Centre for Northern Studies and Research, 56-66. (McGill Subarctic Research Paper 41. Axel Heiberg Island Research Reports. Miscellaneous Papers 2.

Ommanney, C.S. L. Unpublished a. Canadian glacier variations and mass balance changes: 1975-1980 quadrennial report to the Permanent Service on the Fluctuations of Glaciers. Ottawa, Ont., Environment Canada. National Hydrology Research Institute. Snow and Ice Division.

Ommanney, C.S. L. Unpublished b. Quadrennial report to the Permanent Service on the Flucluation of Glaciers on Canadian glacier variations and mass balance changes. Ottawa, Ont., Fisheries and Environment Canada. Inland Waters Directorate. Glaciology Division.

Ostrem, G. 1975. ERTS data in glaciology - an effort to monitor glacier mass balance from satellite imagery. J. Glaciol., 15 73), 403-415.

Ostrem, G. and M. Brugman. 1991. Glacier mass-balance measurements. A manual for field and office work. Saskatoon, Sask., Environment Canada. National Hydrology Research Institute. (NHRI Science Report 4.

Paterson, W.S. B. 1981. The physics of glaciers. Second edition. Oxford, etc., Pergamon Press.

Pelto, M.S. 1988. The annual balance of North Cascade glaciers, Washington, U.S.A., measured and predicted using an activity-index method. J. Glaciol., 34(117), 194-199.

Redpath, B. B. 1965. Seismic investigation of glaciers on Axel Heiberg Island, Canadian Arctic Archipelago. Montréal, Qué., McGill University. Jacobsen-McGill Arctic Research Expedition 1959-1962. Axel Heiberg Island Research Reports. Geophysics 1.)

Rogerson, R.J. 1986. Mass balance of four cirque glaciers in the Torngat Mountains of northern Labrador, Canada. J. Glaciol., 32 (111), 208-218.

Sagar, R. B. 1964. Meteorological and glaciological observations on the Gilman Glacier, northern Ellesmere Island, 1961. Geogr. Bull. 22, 13-56.

Trabant, D. C. and L. R. Mayo. 1985. Estimation and effects of internal accumulation on five glaciers in Alaska. Ann. Glaciol., 6, 113-117.

Vinnikov, K. Ya., P. Ya. Groisman and K. M. Lugina. 1990. Empirical data on contemporary global climate changes temperature and precipitation). 7. Climate, 3, $662-677$.

Walsh, J. E. and W. L. Chapman. 1990. Short-term climatic variability of the Arctic. J. Climate, 3 2), 237-250.

Weiss, J. 1984. Massenhaushalt eines Gletschers, Fragen an glaziologische Untersuchungen und die Resultate der Messreihe am White Glacier in der kanadischen Arktis. Diplomarbeit, Geographisches Institut, University of Zürich and ETH.

Woo, M.-k., R. Heron, P. Marsh and P. Steer. 1983. Comparison of weather station snowfall with winter snow accumulation in High Arctic basins. Atmosphere-Ocean, 21 (3), 312-325.

Young, G.J. 1972. White Glacier mass balance. In Müller, F. and 6 others, eds. International Geographical Union, Fïeld Tour Ea 2, Arctic Archipelago I, 22nd International Geographical Congress. Montréal, Qué., McGill University, 25-30. (Axel Heiberg Island Research Reports. Miscellaneous Papers.)

Young, G. J. 1981. The mass balance of Peyto Glacier, Alberta, Canada, 1965 to 1978. Arct. Alp. Res., 13 (3), 307-318.

Zwiers, F.J. and H. von Storch. 1995. Taking serial correlation into account in tests of the mean. 7. Climate, 8, 336-351. 